\title{
The host specificity of the candidate biological control agent Diadromus collaris (Gravenhorst) (Hymenoptera: Ichneumonidae)
}

\author{
by
}

\author{
Christine Cock
}

A thesis submitted to the Faculty of Graduate Studies and Research in partial fulfillment of the requirements for the degree of MASTER OF SCIENCE IN BIOLOGY

CARLETON UNIVERSITY

Ottawa, Ontario, Canada

(C)2018, Christine Cock 


\begin{abstract}
Diadromus collaris (Gravenhorst) (Hymenoptera: Ichneumonidae), a solitary pupal endoparasitoid of Plutella xylostella (Linnaeus) (Lepidoptera: Plutellidae), is a candidate for introduction into Canada as a biological control agent. It is important to assess the parasitoid's host specificity before its release. To maximize the wasp's expressed host range, I tested five variables to determine which experimental conditions would motivate D. collaris to oviposit. Of these variables, wasp diet, exposure length, and the presence or absence of diamondback moth cocoons resulted in statistically significant differences in $D$. collaris emergence or diamondback moth mortality. To determine the parasitoid's fundamental host range, I exposed pupae from eight species of non-target Lepidoptera to female D. collaris in a series of no-choice tests. Three species, Plutella armoraciae, Plutella porrectella, and Acrolepiopsis assectella, were suitable hosts for D. collaris development. The results from this study provide insight into the suitability of the parasitoid for introduction into Canada.
\end{abstract}




\section{Acknowledgements}

I would first like to thank my co-supervisors, Drs. Peter Mason and Naomi Cappuccino, for their guidance and support throughout this project. Their encouragement and expertise were invaluable. Thanks also to my committee member Dr. Risa Sargent for her input in the development of this project.

Secondly I would like to extend my gratitude to all those in the Mason lab who contributed to my thesis over the last two years. There were those who helped with the rearing of innumerable diamondback moths: Alicia Rochette, Jenni Velichka, Rayan Ghadieh, and most of all, Ana Maria Farmakis. A special thank you goes to Andrea Brauner, my co-occupier of AAFC building 136, who was always around to answer questions, join in a laugh, or provide me with a much needed Sherwood sandwich. Thank you also to Jake Miall, who was always willing to listen to new ideas, and who was an enthusiastic collection partner on our field trip to Guelph. Of course I must also thank Nadine Gaskell, my fellow gingerine, whose incredible work ethic and cheerful presence were pivotal in the completion of this project. I could never have completed my thesis without the help I received from all of my wonderful colleagues.

Finally, I would like to thank my friends and family, who patiently allowed me to schedule all of our social events around my experiment timetable for the last two years. Your support, encouragement (and vehicles!) were always appreciated. 


\section{Table of Contents}

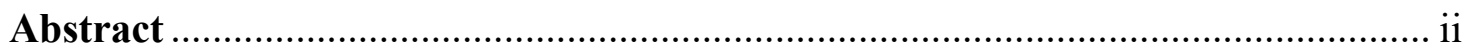

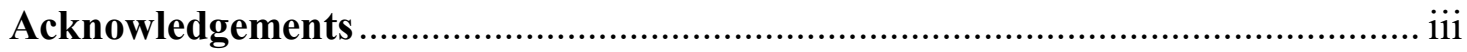

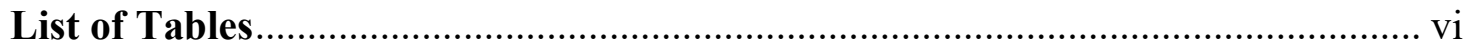

List of Figures ................................................................................................. vii

List of Appendices ....................................................................................... viii

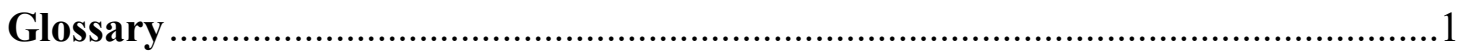

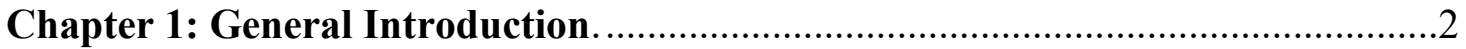

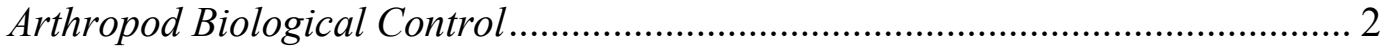

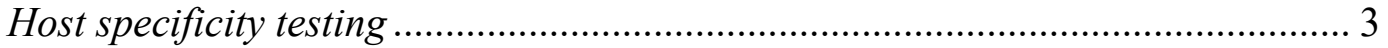

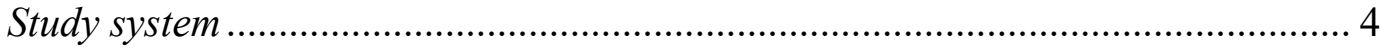

Life history characteristics of diamondback moth and Diadromus collaris .......... 6

Thesis objective and experimental approach ..................................................... 7

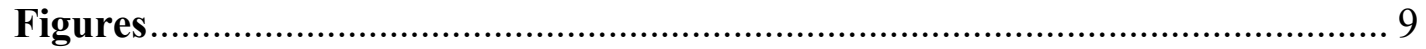

Chapter 2: Establishing host range testing parameters for Diadromus collaris: maximizing the parasitoid's motivation to oviposit. .........................................10

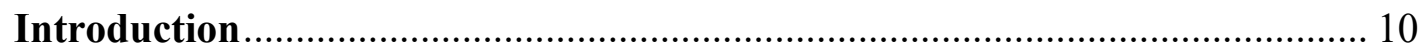

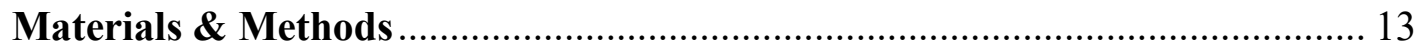

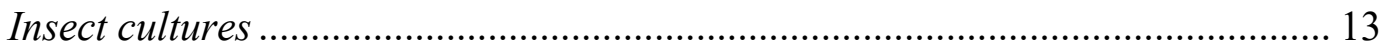

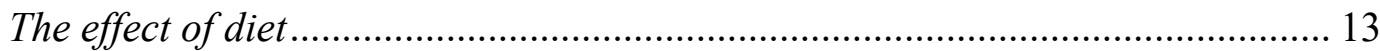

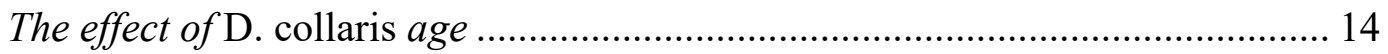

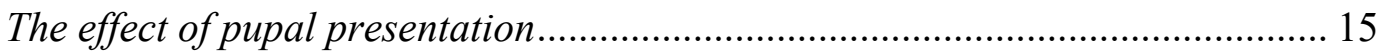

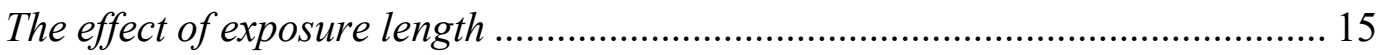

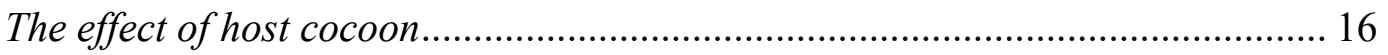

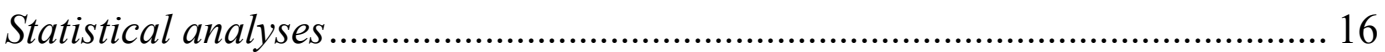

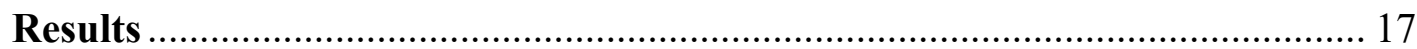

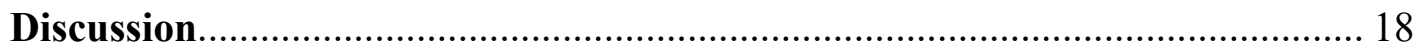

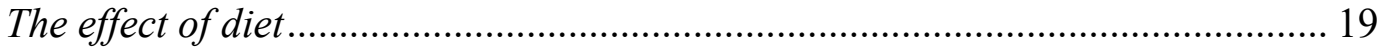

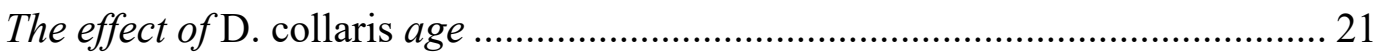

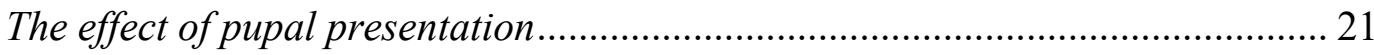

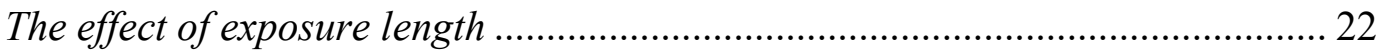

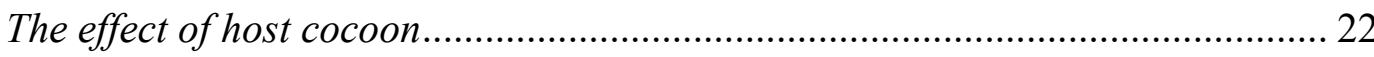

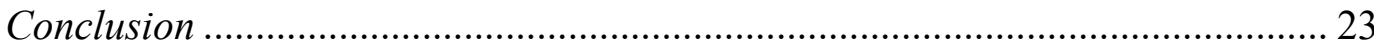




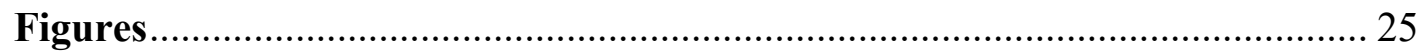

Chapter 3: Determining the fundamental host range of Diadromus collaris. ........30

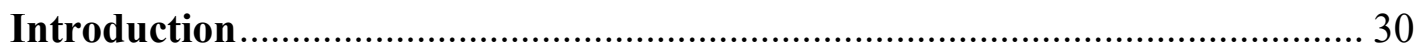

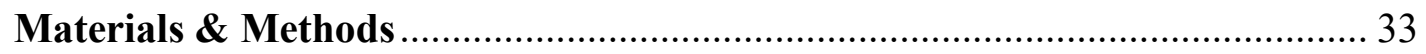

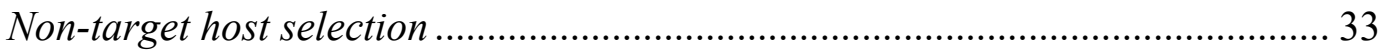

Rearing of target and non-target hosts ....................................................... 34

Rearing and preparation of Diadromus collaris ............................................. 35

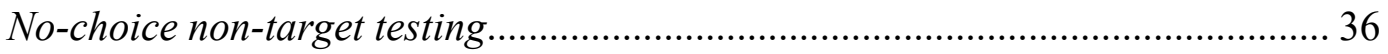

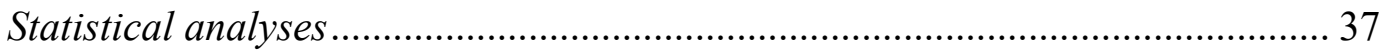

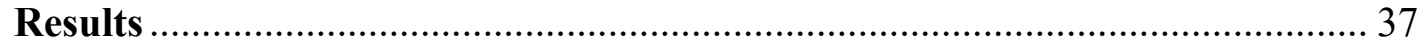

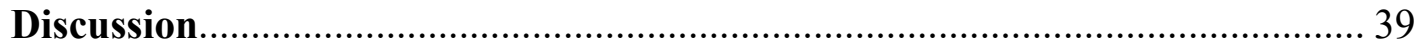

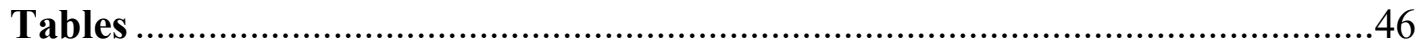

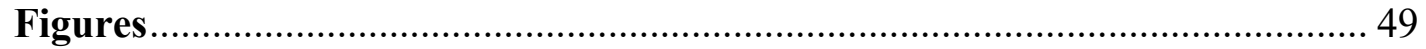

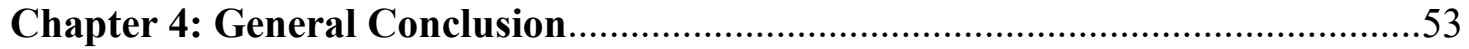

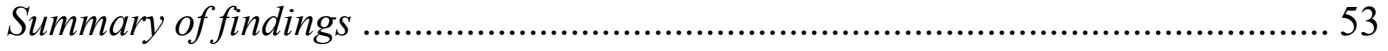

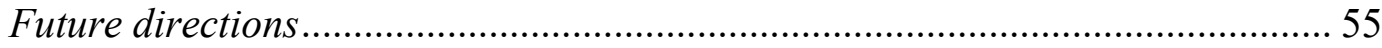

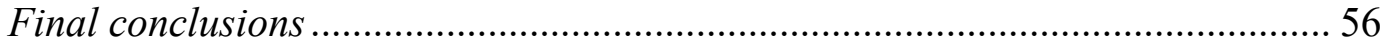

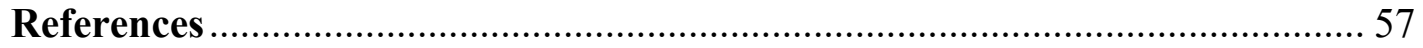

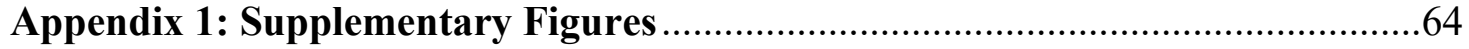




\section{List of Tables}

Table 3.1: Preliminary non-target test list for Diadromus collaris (Hymenoptera:

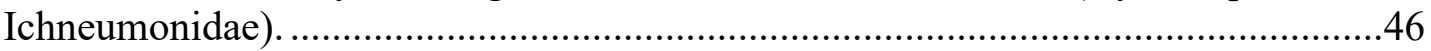

Table 3.2: Non-target test list for Diadromus collaris (Hymenoptera: Ichneumonidae). 48 


\section{List of Figures}

Figure 1.1: Adult female D. collaris parasitizing a diamondback moth pupa. 9

Figure 2.1: Offspring produced by female Diadromus collaris wasps fed for seven days on different diet treatments (Mean $\pm \mathrm{SE})(\mathrm{n}=10$ for each treatment).

Figure 2.2: Offspring produced by female Diadromus collaris wasps of different ages $($ Mean $\pm \mathrm{SE})(\mathrm{n}=11$ for each treatment $)$.

Figure 2.3: Number of Diadromus collaris that emerged from diamondback moth pupae presented on a cabbage plant, unsecured on a filter paper, or secured to a sponge with minuten pins.

Figure 2.4: Number of Diadromus collaris offspring that emerged after two successive exposures to diamondback moth pupae for a period of 6 hours, 12 hours or 24 hours

Figure 2.5: (a) Number of emerged Diadromus collaris (b) and diamondback moth mortality for diamondback moth pupae provided to $D$. collaris with their cocoons either intact or absent $(* \mathrm{p}<0.05)$.

Figure 3.1: Schematic of no-choice host range tests for the determination of the fundamental host range of Diadromus collaris.

Figure 3.2: Percent Diadromus collaris emergence from non-target species Plutella porrectella, Plutella armoraciae and Acrolepiopsis assectella compared to percent emergence from simultaneous target diamondback moth controls after a $24 \mathrm{~h}$ exposure $(* \mathrm{p}<0.05 * * * \mathrm{p}<0.001)$. The number of replicates for each species are shown in parenthesis.

Figure 3.3: Moth emergence from the non-target species Plutella porrectella, Plutella armoraciae, Acrolepsis assectella, Ypsolopha dentella, Athrips mouffetella, Lobesiodes euphorbiana and Pieris rapae exposed to Diadromus collaris for 24 hours compared to emergence from non-target control pupae not exposed to wasps $(* * * \mathrm{p}<0.001)$. The number of replicates for each species and treatment are shown in parenthesis.

Figure 3.4: Flow-chart taken from van Lenteren et al., (2006) depicting a hierarchical approach to host range testing for candidate biological control agents (NT= nontarget). 


\section{List of Appendices}

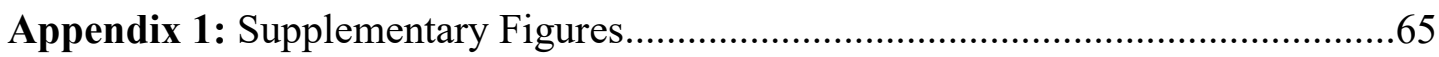




\section{Glossary}

Alien species: a non-native species.

Ecological host range: the current and evolving set of species that are used for reproduction or prey by an organism in the field (Onstad and McManus, 1996).

Endoparasitoid: a parasitoid that completes its development within its host.

Fundamental host range: the host species that are attacked and that support development of an organism in a laboratory environment (Onstad and McManus, 1996).

Host-feeding: the act of feeding on haemolymph or other tissues from a host (Jervis and Kidd, 1986).

Host specificity: the number of species that are attacked by an organism.

Integrated pest management (IPM): An approach to pest control that integrates several pest management techniques with the aim of keeping pest populations below an economic injury level.

Invasive species: An alien species that causes harm to human health, environmental disturbance, or is economically costly.

Monophagous: an organism that exploits only one type of host.

Natural enemy: an organism that kills or decreases the reproductive potential of another organism (e.g., parasitoids, predators, pathogens).

Non-target: any species other than the target species that may be attacked by a biological control agent.

Oligophagous: an organism that exploits only a few closely related hosts.

Oviposition: the act of depositing an egg in a host.

Parasitoid: an organism which completes its development by killing its host.

Superparasitism: the parasitism of a single host by multiple organisms within the same species.

Synovigenic: an organism which emerges without mature eggs and continues to produce eggs throughout its lifespan (Jervis and Kidd, 1986).

Target: the pest species against which a biological control agent may be released. 


\section{Chapter 1: General Introduction.}

\section{Arthropod Biological Control}

Accidentally introduced alien species, which are increasingly common in the era of globalization, threaten biodiversity and have negative economic consequences (Vitousek et al., 1997). These invasive species may disrupt essential ecosystem services; for instance, non-native arthropod pests can dramatically reduce productivity in both forestry and agricultural settings (Pimentel, 1986). If the natural enemies which suppress an exotic population in its native range do not migrate to the novel habitat, then the pest species may further proliferate (i.e., enemy release) (Keane and Crawley, 2002). Chemical insecticides are widely used to mitigate the negative effects of such invasions, but this solution may result in toxic effects to other species in the ecosystem, bioaccumulation in the food chain, or the evolution of resistance by pest populations. The introduction of a natural enemy from the pest's native range (i.e., importation biological control) can offer a sustainable and costeffective alternative to the application of pesticides (Fisher et al., 1999).

While biological control is a critical component of integrated pest management (IPM), the introduction of new biological control agents must be undertaken with caution. It is important to consider the potential for unintended consequences to species already present in the system, and in particular host range expansion to non-target native or beneficial species (van Lenteren et al., 2003). Ideal candidates for biological control are either monophagous, attacking the target pest species exclusively, or narrowly oligophagous, primarily attacking the target species but also related species to a lesser degree (van Lenteren et al., 2003). Failing to accurately determine the host specificity of a candidate biological control agent prior to its release can result in detrimental effects to 
non-target species. For instance, the introduction of Compsilura concinnata (Meigen) (Diptera: Tachinidae), a generalist fly which was released in the early 1900's as a biological control agent for the suppression of gypsy moth, Lymantria dispar Linnaeus (Lepidoptera: Erabidae), has had a significant negative effect on some native silk moth populations (Saturniidae) (Boetner et al., 2000). Another example is the weevil species Rhinocyllus conicus Frölich (Coleoptera: Curculionidae), released for the suppression of non-native thistles in North America, exhibited a host range expansion to native thistles including the endangered Platte thistle, Cirsium canescens Nuttall (Asteraceae) (Louda et al., 1997). In this case, it was known at the time of release (1969) that $R$. conicus would attack thistles in the genera Carduus, Cirsium, Silybum and Onopordum in addition to the target, Carduus nutans Linnaeus (Asteraceae) (Harris, 1984), but all thistles were then considered weeds. These examples highlight the need for host specificity testing of candidate biological control agents before they are released.

\section{Host specificity testing}

There has been considerable progress towards a standardized procedure for host specificity testing and, although the particular protocols vary for each candidate, a general framework has emerged. First, literature records should be consulted to determine known hosts of the agent, and field surveys in the native region of the agent should be conducted, particularly where records are sparse (Sands and Van Driesche, 2004). These recorded hosts, and appropriate non-target species, should be offered to the candidate biological control agent to determine whether non-targets can support development of or serve as prey for the agent in the laboratory (i.e., the fundamental host range (Onstad and McManus, 1996)). Because the foraging conditions of the candidate will vary widely under natural 
conditions it is not possible to test all potential environments; however, it is important to take a cautious approach, particularly given the irreversible nature of such introductions. In the first stages of host specificity testing, it is preferable to determine the widest possible host range under laboratory conditions. To maximize a candidate's expressed host range, it is necessary to design a test protocol that matches the physiology of the particular natural enemy under consideration. The current and evolving set of species that are attacked in the field (i.e., the ecological host range (Onstad and McManus, 1996)) is generally narrower than the fundamental host range, so non-target species that elicit positive results in the laboratory should then be tested under conditions that mimic those found in nature (Barratt et al., 2010).

\section{Study system}

The diamondback moth, Plutella xylostella Linnaeus (Lepidoptera: Plutellidae), is an invasive pest species that targets brassicaceous plants. Each year, the moth causes US\$45 billion in damages globally (Zalucki et al., 2012). In Canada, periodic outbreaks of diamondback moth cause significant damage to canola, Brassica napus Linnaeus and Brassica rapa Linnaeus (Brassicaceae), and these outbreaks are predicted to become more prevalent with climate change (Dosdall et al. 2008, 2011). In many regions of the world, diamondback moth is the greatest inhibitor of Brassica spp. production; yield reduction can reach up to $90 \%$ (Verkerk and Wright, 1996). Thought to originate from the Mediterranean (Harcourt, 1954; Talekar and Shelton, 1993), diamondback moth is now established worldwide wherever crucifers are grown, and is believed to have the most universal distribution of all Lepidoptera (Meyrick, 1928; Talekar and Shelton, 1993). Its prevalence as a pest species began in the 1940s with the prophylactic application of 
insecticides (Talekar and Shelton, 1993). The resulting elimination of natural enemy populations produced a cycle of increasingly intense pesticide applications. Diamondback moth has an unrivaled ability to evolve insecticide resistance; it was the first species to develop resistance to DDT and subsequently to Bacillus thuringiensis Berliner serovar kurstaki (Bacillaceae) and in some areas is now resistant to all major classes of pesticides (Talekar and Shelton, 1993). Control failures have made brassica production unfeasible in some parts of the world. Increasingly concentrated and frequent insecticide applications pose health risks to farmers and laborers, and residues on vegetables are common.

Natural enemies account for significant mortality of the diamondback moth via predation and parasitism in its native European range. Worldwide, 135 species have been recorded to attack either the egg, larval or pupal stages (Delvare, 2004). In Canada, three main parasitoid wasps contribute to diamondback moth mortality: Diadegma insulare (Cresson) (Hymenoptera: Ichneumonidae) and Microplitis plutellae (Muesbeck) (Hymenoptera: Braconidae) are both larval parasitoids, and Diadromus subtilicornis (Gravenhorst) (Hymenoptera: Ichneumonidae) is a pupal parasitoid (Braun et al., 2004; Sarfraz et al. 2005). Although these species can impose mortality rates of up to 58\% (Braun et al., 2004), they are ineffective at controlling diamondback moth below economic thresholds, and insecticides must routinely be applied. Given the current emphasis on environmental sustainability, a renewable alternative in the form of biological control would be preferable.

Diadromus collaris (Gravenhorst) (Hymenoptera: Ichneumonidae), a solitary pupal endoparasitoid of diamondback moth (Figure 1.1), is a candidate for introduction into Canada. Diadromus collaris has a widespread natural distribution, with native populations 
throughout Europe, South Africa, and much of Asia (Furlong et al., 2013), and introduced populations in New Zealand, Australia, the Cook Islands, and Malaysia (Talekar and Shelton, 1993). In the Cameroon Highlands of Malaysia, a post-release field study estimated parasitism by D. collaris of $8.9 \%$ (Chua and Ooi, 1986). Australian introductions were even more successful, with $72-93 \%$ parasitism observed in the 1971-1974 seasons and a clear reduction in damage to cabbage crops (Goodwin, 1979 \& Hamilton, 1979). More recently, $D$. collaris was the most commonly observed diamondback moth parasitoid in Queensland, Australia (Furlong et al., 2004). A study in Hangzhou China found that collective rates of diamondback moth parasitism averaged $10-60 \%$ but occasionally reached the $80-90 \%$ range, and $D$. collaris was the most commonly observed pupal parasitoid (Liu et al., 2000). The historical success of D. collaris makes it a promising candidate for introduction in Canada, but before its widespread release it is crucial to assess the parasitoid's host specificity.

Life history characteristics of diamondback moth and Diadromus collaris

Diamondback moth mate within a day of emergence, and oviposition generally begins soon thereafter (Talekar and Shelton, 1993). The ovipositional period lasts up to four days, during which females lay between 11 and 188 eggs (Harcourt, 1954). Once hatched, neonate larvae burrow into the leaves of their brassica host plants and feed internally (Talekar and Shelton, 1993). The $1^{\text {st }}$ instar larvae exit these leaf mines to molt and proceed to feed on the underside of the leaf surface. Larvae develop through four instars, after which they form a loosely woven cocoon in which they pupate. Development time from egg to adult will vary depending on the temperature, but at $24^{\circ} \mathrm{C}$ the process takes $15.3 \pm 0.22$ days (Liu et al., 2002). Temperate regions have between four and six 
generations per year (Harcourt, 1954), while tropical regions may have up to twenty overlapping generations (Talekar and Shelton, 1993). The ability of diamondback moth to overwinter in its northern host range is disputed (Dancau et al., 2018), but diamondback is highly migratory, and infestations occur annually when low altitude winds carry new populations northward (Dosdall et al., 2001).

The parasitoid Diadromus collaris completes its development inside a diamondback moth pupa in four larval instars, after which it forms a pupa which lacks a cocoon (Zhao et al., 2014). Development from egg to adult at $22.5^{\circ} \mathrm{C}$ is completed in 14.5 days (Wang and Liu, 1998). Female D. collaris emerge without mature eggs, but most females have eggs in their ovaries within 24 hours of eclosion (Sakanoshita et al., 1987) and begin to oviposit at one or two days old (Liu et al., 2001). At $25^{\circ} \mathrm{C}$ honey fed females have a mean oviposition period of $11.5 \pm 1.8$ days and parasitize a mean of $43.7 \pm 5.2$ pupae, with approximately $96 \%$ adult emergence (Liu et al., 2001). As with many other hymenopteran parasitoids, $D$. collaris injects a venom into its host upon oviposition, to facilitate the development of the parasitoid offspring and suppress host immune responses (Zhao et al., 2017). Females will occasionally pierce diamondback moth pupae with their ovipositor and consume hemolymph (i.e., host feeding), likely to acquire additional protein and enhance egg development (Sakanoshita et al., 1987; Lloyd, 1940). Both males and females generally mate soon after emergence (24-48 hours), and unmated females produce only male progeny (Liu et al., 2001). Diadromus collaris are believed to overwinter as adults (Valemberg and Valo, 1974).

Thesis objective and experimental approach 
The overall objective of this thesis is to determine the widest possible host range of the candidate biological control agent Diadromus collaris. First, I sought to establish which experimental conditions would maximize the parasitoid's expressed host range. The following five experimental parameters were investigated to determine how they may affect the parasitoids' motivation to oviposit: (1) D. collaris diet, (2) D. collaris age, (3) the substrate on which a host is presented, (4) length of exposure, and finally, (5) the presence or absence of a cocoon that surrounds the pupa. Then, to determine the parasitoid's fundamental host range, I conducted a series of no-choice black box tests with eight species of non-target Lepidoptera. I exposed non-target pupae to female D. collaris to assess whether any non-targets were suitable for parasitoid development and/or whether exposure to $D$. collaris increased non-target mortality. The results from these studies will provide valuable information about the suitability of $D$. collaris for introduction into Canada. 


\section{Figures}

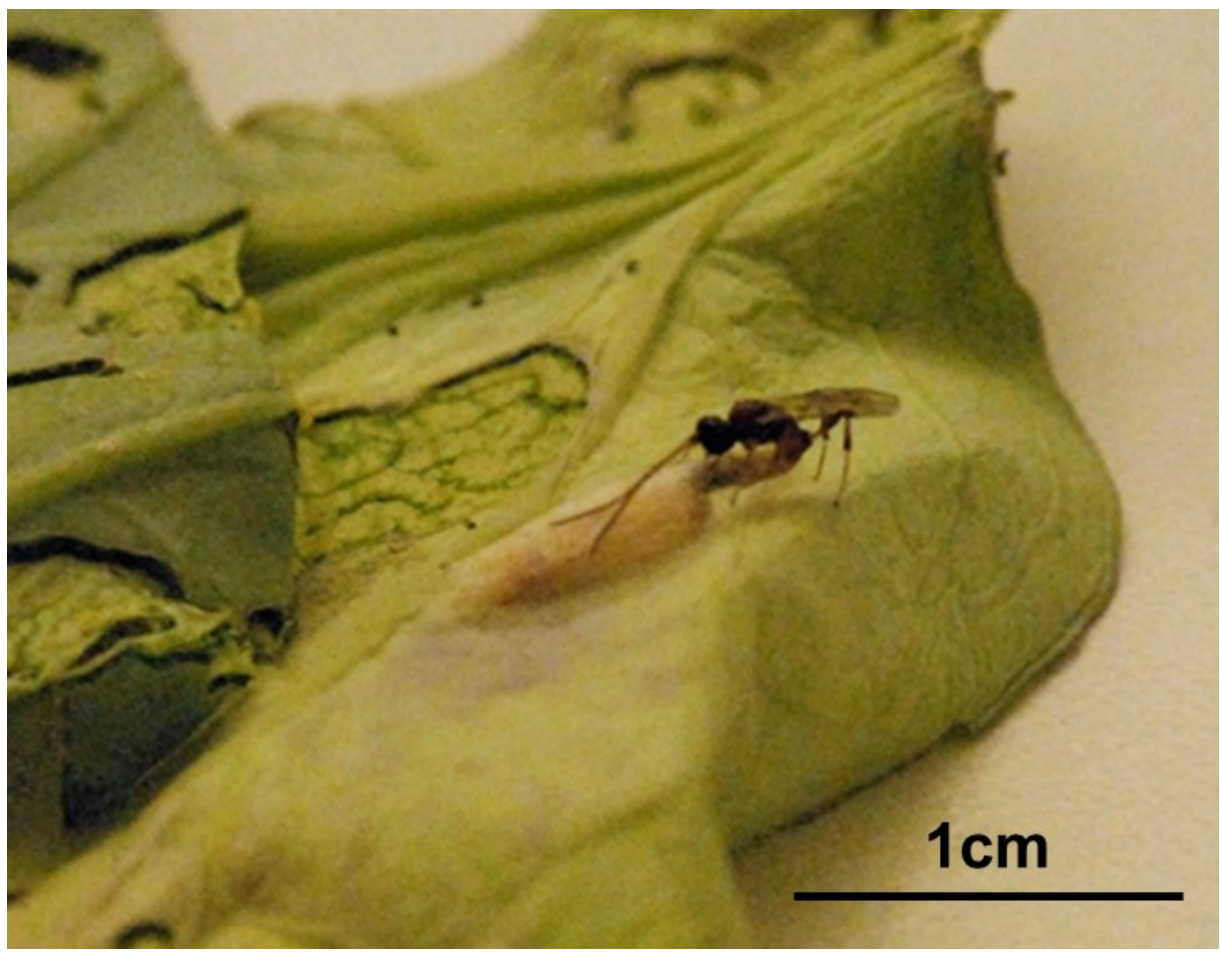

Figure 1.1: Adult female D. collaris parasitizing a diamondback moth pupa. (Photo: C. Cock). 


\section{Chapter 2: Establishing host range testing parameters for Diadromus collaris: maximizing the parasitoid's motivation to oviposit.}

\section{Introduction}

Biological control is an important component of an integrated pest management (IPM) strategy to suppress pest populations and it can offer a sustainable and cost-effective alternative to the application of insecticides (Fisher et al., 1999). However, the introduction of any biological control agent must be undertaken with caution. It is important to consider the potential for unintended consequences to species already present in the system, and in particular, host range expansion to non-target native or beneficial species (van Lenteren et al., 2003). Ideal candidates are either monophagous, attacking the target pest species exclusively, or else narrowly oligophagous, primarily attacking the target species but also related species to a lesser degree (van Lenteren et al., 2003). Biological control agents that establish and disperse widely are not likely to cause any negative effects to non-target species if they are host specific to the target pest.

Consequently, it is important to determine the host specificity of a candidate biological control agent before its release. In its simplest form, this involves providing the candidate with appropriate non-target species to determine whether they can support development of or serve as hosts for the agent. In practice, however, it can be difficult to approximate a species' ecological host range (i.e., the current and evolving list of species used for reproduction or prey in the field (Onstad and McManus, 1996)) in a laboratory setting. A number of factors limit this ability: there may be limited information available about the phylogeny or life history traits of non-target species, it may be difficult to obtain rare non-targets in sufficient numbers, and the initial list of species to test can be impractically long given the work required to collect and rear non-target insects (Kuhlman 
et al., 2006; Van Driesche, 2004). Another major concern is how artificial test conditions may alter the candidate species' foraging behavior; it is well-established that non-natural conditions can artificially inflate the rate of attack on less-preferred non-target species (e.g., Cameron and Walker, 1997; Morehead and Feener, 2000; Froud and Stevens, 2002; Haye et al., 2005). Because the foraging conditions of the candidate will vary widely under natural conditions, it is not possible to test all potential environments; however, given the irreversible nature of such introductions it is important to take a cautious approach. Particularly in the first stages of host specificity testing, it is preferable to determine the widest possible host range under laboratory conditions (i.e., the fundamental/physiological host range (Onstad and McManus, 1996)) than to risk a false negative for a non-target species that is in fact suitable.

To avoid rejections of suitable non-target species, it is crucial to consider how testing conditions may influence the motivation of a candidate biological control agent to forage and/or oviposit on any given non-target species. For instance, the informational state of a candidate has been shown to influence its likelihood to accept a less-preferred nontarget (e.g., Fujiwara et al., 2000; Petitt et al., 1992). Arthropods can learn from previous host experience; exposure to the target species prior to testing could bias the candidate against attacking a non-target (Vet and Dicke, 1992). Using naïve individuals is preferable, to prevent prior conditioning from influencing the results. Of course, this may not be possible if the candidate agent is synovigenic (i.e., does not emerge with mature eggs) and must host-feed on haemolymph or other tissues from their hosts to acquire protein for egg development. The physiological state of the candidate should also be considered; foraging/ovipositional behavior can be influenced by seemingly subtle factors such as 
nutritional status, mating status, age, size, and egg load (Withers and Browne, 2004). These authors discuss how the combination of testing environment, physiological state, and informational state can influence a candidate's motivational state, and they provide a list of suggestions for host range testing environments. In the case of parasitoids, they recommend using sugar-deprived, older females to maximize their motivation to oviposit. They stress, however, that what is ideal for one candidate may not be ideal for all, and it is important to tailor the design of such host range tests to fit the physiology of the particular natural enemy under consideration.

Diadromus collaris (Gravenhorst) (Hymenoptera: Ichneumonidae) is a solitary pupal endoparasitoid of diamondback moth, Plutella xylostella (Linnaeus) (Lepidoptera: Plutellidae), a major pest of brassicaceous plants. The historical success of D. collaris in its native and introduced ranges (e.g., Chua and Ooi, 1986; Goodwin, 1979; Hamilton, 1979; Furlong et al., 2004; Liu et al., 2000) makes it a promising candidate for introduction into Canada, but its host specificity must first be established. However, before conducting no-choice host specificity tests to assess the parasitoid's fundamental host range, it is imperative to determine which experimental conditions will maximize the motivation of D. collaris to oviposit in its usual host. This assumes that conditions which make $D$. collaris more likely to attack diamondback moth pupae will also increase its motivation to oviposit when presented with a non-target pupa. The following five experimental parameters were investigated to determine how they may affect the wasps' motivational state: (1) D. collaris diet; (2) D. collaris age; (3) the substrate on which a host is presented; (4) length of exposure; and (5) the presence or absence of a cocoon that surrounds the pupa. 


\section{Materials \& Methods}

Insect cultures

Diadromus collaris were obtained from Delémont, Switzerland in 2016 and a culture was maintained in containment at $21^{\circ} \mathrm{C} \pm 1^{\circ} \mathrm{C}$ and a $16: 8 \mathrm{~L}: \mathrm{D}$ photoperiod cycle with $40 \pm 25 \%$ relative humidity. New individuals from the same population were added in 2017 and 2018. Host diamondback moth were reared on cabbage plants, Brassica oleracea L. var. capitata (Brassicaceae). Diamondback moth pupae were exposed to mated D. collaris females for 24-48 hours to allow oviposition. Parasitized pupae were placed in clear plastic dishes (90 x $25 \mathrm{~mm}$, Semadeni AG, Ostermundigen, Switzerland) and maintained at the conditions described above. Upon emergence, parasitoids were provided with honey and a pollen paste. Bee pollen granules (Wild Country Bee Pollen) were mixed with distilled water in a 1:1 ratio to form the paste, which was provided on $1 \mathrm{~cm}$-long cotton dental wicks soaked in distilled water. These were changed every second day.

\section{The effect of diet}

The number of progeny produced by $D$. collaris females provided with different food resources was assessed. For each replicate (10 replicates overall), within 24 hours of emergence, 11 unmated $D$. collaris females were placed into individual clear plastic dishes (90 x $25 \mathrm{~mm}$, Semadeni AG, Ostermundigen, Switzerland) and provided with one of the following 11 treatments:

- distilled water

- $10 \%$ sucrose solution

- distilled water + honey smear

- $10 \%$ sucrose solution + honey smear

- distilled water + bee pollen paste

- $10 \%$ sucrose solution + bee pollen paste 
- distilled water + honey smear + bee pollen paste

- $10 \%$ sucrose solution + bee pollen paste + honey smear

- 5 diamondback moth pupae + distilled water

- 5 diamondback moth pupae $+10 \%$ sucrose solution

- 5 diamondback moth pupae + distilled water + honey smear

The $10 \%$ sucrose solution and the distilled water were provided on $1 \mathrm{~cm}$-long cotton dental wicks soaked in solution, and pollen was provided by dipping either the sucrose wick or the distilled water wick halfway into the paste. After 24 hours, the diamondback moth pupae were removed and two male $D$. collaris were added to each plastic dish. These males were allowed to mate with the females for the next 48 hours. All food sources were changed every second day, for seven days. The seven-day-old wasps were then provided with 10 fresh diamondback moth pupae for a period of 24 hours. These exposed pupae were removed and monitored for $D$. collaris emergence. Parasitoid emergence among diet treatments was compared.

The effect of $\mathrm{D}$. collaris age

The number of progeny produced by $D$. collaris females of differing age was compared. For each replicate (11 replicates overall), within 4 hours of emergence, seven female wasps were separated into clear plastic dishes $(90 \times 25 \mathrm{~mm}$, Semadeni AG, Ostermundigen, Switzerland) and randomly assigned to a treatment ranging from three to nine days. Two males were added to each dish for a 48-hour mating period. After three days ( 72 hours), females in the first treatment were provided with 10 fresh diamondback pupae for a period of 24 hours. The exposed pupae were then removed, placed in a clear plastic dish, and monitored for D. collaris emergence. Subsequent treatments were conducted the same way on each day over the following week. D. collaris emergence 
among age treatments was compared.

\section{The effect of pupal presentation}

The number of progeny produced by $D$. collaris females presented with diamondback moth pupae on different substrates was compared. For each replicate (20 replicates overall), within 24 hours of emergence, female wasps were separated into clear plastic dishes (101 x $54 \mathrm{~mm}$, Semadeni AG, Ostermundigen, Switzerland) with three females in each. Three males were added to each dish and removed after 48 hours. Once wasps had reached an age of seven days, each female wasp was placed in a clear plastic dish (90 x 25 mm, Semadeni AG, Ostermundigen, Switzerland). For 24 hours, each wasp was provided with one of the following: a diamondback moth pupa on a $2 \mathrm{~cm} \mathrm{x} 2 \mathrm{~cm}$ cabbage leaf, a pupa that was unsecured on a filter paper, or a pupa secured to a sponge by pinning two insect minuten pins through the cocoon. The exposed pupae were then removed, placed in clear plastic dishes and monitored for D. collaris emergence. The number of $D$. collaris that emerged from diamondback moth pupae presented on different substrates was compared.

\section{The effect of exposure length}

The number of progeny produced by $D$. collaris females that had access to hosts for different lengths of time were compared. For each replicate (20 replicates overall), within 24 hours of emergence, female wasps were separated groups of three individuals and placed into clear into plastic dishes $(101$ x 54 mm, Semadeni AG, Ostermundigen, Switzerland). Three males were added to each dish and removed after 48 hours. Once the female wasps had reached an age of seven days, the individuals in each group of three were 
assigned to one of three exposure treatments (6-, 12- or 24-hour exposure) and transferred into separate clear plastic dishes $(90$ x $25 \mathrm{~mm}$, Semadeni AG, Ostermundigen, Switzerland). Each was provided with a single pupa secured on a sponge with minuten pins. After the prescribed exposure time, the process was repeated with a new pupa. The exposed pupae were then removed, placed in clear plastic dishes and monitored for $D$. collaris emergence. Diadromus collaris emergence among exposure times was compared.

\section{The effect of host cocoon}

The effect of cocoon presence or absence on progeny produced by $D$. collaris females and on host mortality was determined. Within 24 hours of emergence, 40 female wasps were separated into clear plastic dishes $(101$ x 54 mm, Semadeni AG, Ostermundigen, Switzerland) with ten females in each. Ten males were added to each dish and removed after 48 hours. Once wasps had reached an age of seven days, individual females were separated into clear plastic dishes $(90$ x $25 \mathrm{~mm}$, Semadeni AG,

Ostermundigen, Switzerland) and provided with a diamondback moth pupa with or without a cocoon (the mesh cocoons were removed with forceps just prior to exposure) for a period of 24 hours. Host pupae were secured on sponges with insect minuten pins. Simultaneously, control pupae with and without cocoons were set up as described above but not exposed to $D$. collaris, to determine whether cocoon removal kills host pupae (thus rendering them invalid hosts). D. collaris emergence and total diamondback moth mortality were compared.

\section{Statistical analyses}

Mixed model analyses, with distributions tailored to model error distributions, were 
used to evaluate the effects of diet, age, and exposure length on D. collaris emergence. The effects of diet and age on D. collaris emergence were analyzed using generalized linear models (GLM) with a Poisson distribution and log link. Likelihood ratio Chi-squared tests were used to evaluate model fit, followed by a Tukey's multiple comparison (glht in the R multcomp package) to evaluate post-hoc differences among the levels of diet. D. collaris emergence counts for each exposure length were compared using a generalized linear mixed model (GLMM) with a binomial distribution and a log link. Exposure length was treated as a fixed factor and wasp ID as a random factor. A Wald Chi-square test was used to evaluate main effects significance (lme4 package). A Tukey's multiple comparison (glht in the R multcomp package) was used to evaluate post-hoc differences in emergence for each exposure length. Diadromus collaris emergence counts among pupal presentation substrates and emergence counts from pupae with and without cocoons were compared using Chi-square tests of association. Diamondback moth mortality for pupae with and without cocoons was also compared using a Chi-square test of association. All analyses were performed using R-studio version 3.4.4 ( $\mathrm{R}$ core team, 2018).

\section{Results}

Offspring emergence varied significantly among diet treatment types (likelihood ratio test, $\left.\chi^{2}=141.95, \mathrm{df}=10, \mathrm{p}<0.0001\right)$ but post-hoc Tukey's comparison tests showed no significant differences among the different diet treatments, likely due to the large number of pairwise comparisons $(\mathrm{n}=55)$. For wasps deprived of a carbohydrate (i.e., the water treatment and the host-feeding + water treatment), offspring emergence was zero, as none of the females in these treatments survived to day seven when females were presented with hosts for oviposition (Figure 2.1). 
Offspring emergence did not vary significantly among age treatments $\left(\chi^{2}=3.5824\right.$, $\mathrm{df}=6, \mathrm{p}=0.733)\left(\right.$ Figure 2.2), or among the substrate on which hosts were presented $\left(\chi^{2}=\right.$ $1.558, \mathrm{df}=2, \mathrm{p}=0.459)($ Figure 2.3).

Diadromus collaris emergence was significantly different among exposure lengths $\left(\chi^{2}=5.952 \mathrm{df}=2, \mathrm{p}=0.031\right)$. Post-hoc Tukey's comparisons showed that a 24-hour exposure resulted in significantly higher wasp emergence than a 12-hour exposure $(z=2.60$, $\mathrm{p}=0.025)$ (Figure 2.4).

Diadromus collaris emergence did not differ significantly depending on the presence or absence of a cocoon on the diamondback moth pupae $\left(\chi^{2}=0.921, \mathrm{df}=1, \mathrm{p}=\right.$ 0.337) (Figure 2.5). Total diamondback moth mortality, however, was significantly higher for pupae that were provided with their cocoons intact than for pupae provided without cocoons $\left(\chi^{2}=5.714, \mathrm{df}=1, \mathrm{p}=0.017\right)$. Adult diamondback moth emerged from all of the control pupae which were not exposed to D. collaris, regardless of whether the cocoon had been removed.

\section{Discussion}

This study tests several of the conditions proposed by Withers and Browne (2004) for host specificity testing to maximize motivation of individuals of a candidate species to oviposit. These authors stressed that what is optimal for one candidate may not be ideal for all; it is important to tailor the design of host range tests to fit the physiology and behaviour of individual candidate species. The results from this study provide the basis for a testing protocol for $D$. collaris to maximize its expressed host range, by using offspring emergence and/or diamondback moth mortality as a proxy for the wasp's motivation to oviposit. Of the five variables tested, diet, exposure length, and the presence or absence of diamondback 
moth cocoons resulted in statistically significant differences in D. collaris emergence or diamondback moth mortality, while wasp age and substrate type did not result in significant differences in wasp emergence.

\section{The effect of diet}

Although overall offspring emergence varied significantly among diet treatment types, a post-hoc Tukey's comparison test showed no significant differences among the different diet treatments, likely due to the large number of pairwise comparisons. Although the power to detect small differences was low, the observed trends do have some interesting implications for the diet of $D$. collaris during host range tests.

Withers and Browne (2004) advised that a period of starvation prior to testing could decrease the parasitoids' perception of life expectancy, thereby increasing their motivation to oviposit in lower-ranked hosts. However, Liu et al. (2001) found that D. collaris fed with honey developed twice as many eggs in their ovaries as those fed with water only. Since motivation to oviposit generally increases as egg load builds (Minkenberg et al., 1992), it does not appear that the period of deprivation suggested by Withers and Browne matches the biology of $D$. collaris. In this experiment, none of the carbohydrate-deprived wasps, regardless of whether or not they were provided with pupae for host-feeding, survived to day seven for testing. In a similar experiment performed with the closely related wasp species Diadromus pulchellus Wesmael (Hymenoptera: Ichneumonidae), a solitary pupal parasitoid of Acrolepiopsis assectella Zeller (Lepidoptera: Glyphipterigidae), sugardeprived wasps lived significantly less long and produced significantly fewer offspring than wasps fed with sucrose (Jenner et al., 2012). Jenner et al. suggest that sugar-deprived wasps may have poorer energy reserves, resulting in longer handling times and rest periods. 
Alternatively, sugar-deprived females may experience egg resorption as an energy conservation strategy (Minkenberg et al., 1992). Regardless, Jenner et al. (2012) concluded that the use of $D$. pulchellus fed with sucrose was preferable for host range tests.

Diadromus collaris is synovigenic (i.e., it does not emerge with mature eggs) and consumes haemolymph or other tissues from its hosts to supplement nutrition (Sakanoshita et al., 1987; Lloyd, 1940). Jervis and Kidd (1986) suggested that ichneumonids are able to lay eggs without first host-feeding and will only host-feed when alternatives like honeydew, pollen, nectar or sucrose are unavailable. In contrast, Lloyd (1940) reported that providing pupae for host-feeding results in higher subsequent rates of parasitism by $D$. collaris and noted that even wasps fed with sugar and raisins were observed to host-feed. He suggested that host-feeding provides additional nutrients such as amino acids.

In host range testing, there is a risk in allowing the parasitoid to host-feed before exposing it to non-target test individuals, as learning to recognize host pupae could bias it towards the target (Withers and Mansfield, 2005). Using naïve parasitoids is preferable, in order to prevent conditioning. It was therefore important to determine whether $D$. collaris would require some exposure to diamondback moth pupae for offspring production, or whether it would be possible to make use of naïve parasitoids. In this experiment, wasps provided with pupae in addition to a sugar source did not have significantly more offspring than wasps fed exclusively with sugar and/or pollen paste (Figure 2.1). Although the consumption of haemolymph or other tissues from their hosts may have supplemented nutrition, the additional protein was not essential for egg development. This suggests that the use of naïve wasps, fed with a carbohydrate, is appropriate for host range tests. 
The effect of $\mathrm{D}$. collaris age

Withers and Browne (2004) suggested that older female parasitoids may be less choosy, either because of a perception of reduced life expectancy or because of an increased egg load. In this study, there was no significant difference between wasp emergence for any of the age treatments (Figure 2.2). In previous experiments of lifetime reproductive success, Lloyd (1940) described the maximum oviposition activity of $D$. collaris as occurring around seven days old, and Wang and Liu (1998) determined that at $25^{\circ} \mathrm{C}$ the ovipositional peak occurs from three to seven days old. Sakanoshita et al. (1987) showed that within 24 hours of eclosion most female D. collaris have developed some mature eggs, that wasps have the most eggs in their ovarioles when they are 2-3 days old, and that resorption of eggs begins on the sixth day. Considering these data, it is not necessary to use older wasps; 3 - to 7-day-old $D$. collaris wasps are equally suitable for host range testing.

\section{The effect of pupal presentation}

Withers and Browne (2004) recommended conducting host range testing on an inert surface, given that the presence of the host plant material can affect a wasp's motivation to oviposit. Plant volatiles are known to influence parasitoid searching behavior and host acceptance patterns (Vet et al., 1995). On the other hand, removing pupae from their host plants may make parasitism more difficult for the wasps if they struggle to oviposit in or on an unsecured host. In this experiment, D. collaris emergence was not significantly different among pupae that were provided on their host plant (cabbage), pupae that were unsecured on filter paper, or pupae that were pinned to a sponge with minuten pins (Figure 2.3). This suggests that the removal of pupae from their host-plant does not impede 
oviposition by $D$. collaris, and therefore an inert surface for pupal presentation is appropriate for host range experiments.

\section{The effect of exposure length}

There is evidence that $D$. collaris exhibits superparastitism, which occurs when wasps continuously attempt to parasitize the same pupa (Lloyd, 1940). This can result in host mortality, either as a result of physical damage to the pupa or from competition between parasitoid larvae (Kalmes et al., 1983). Diadromus collaris is only able to detect that a pupa has already been parasitized if parasitoid egg development has progressed for approximately 24 hours (Lloyd, 1940). Ideally, wasps would be exposed to non-target pupae for a longer duration, because over the course of an exposure the acceptance threshold for oviposition is likely to decrease, while the encounter rate increases (Withers and Mansfield, 2005). However, if the exposure is too long then D. collaris may deposit its full egg load into the host and superparasitize the pupa. Diadromus collaris emergence was significantly higher in the 24-hour exposure than in the 12-hour exposure (Figure 2.4); therefore a 24-hour exposure length is appropriate to allow the wasps enough time to locate a host and parasitize it without compromising the emergence. Additionally, a 24-hour exposure allows the wasps to renew their egg load and to oviposit in the second exposure to diamondback moth.

\section{The effect of host cocoon}

When selecting non-target species for host range testing, the first species to eliminate are hosts that cannot be parasitized by the agent, whether because of temporal asynchrony or physical incompatibility (Kuhlmann et al., 2006). Given that it is not 
possible to test every non-target species, it is important to select species that are more likely to be suitable for parasitism. Diamondback moth forms a loosely-woven cocoon around the pupa. If the presence of a cocoon is a critical cue for oviposition by $D$. collaris, then any non-targets without such a feature may be eliminated from the non-target test list or given a lower testing priority. In this experiment, although there was no statistically significant difference in the emergence of $D$. collaris from diamondback moth pupae with or without cocoons, the presence of a cocoon resulted in significantly greater diamondback moth mortality (Figure 2.5). The mortality of pupae that had their cocoons intact was $100 \%$, suggesting that the cocoon stimulates either superparasitism or host-feeding, both of which could result in host mortality without the production of parasitoid offspring. Cocoons may be attractive due to the presence of kairomones (e.g., from remnants of larval feces held in the cocoon), as has been shown in the related species Diadromus pulchellus with its host Acrolepiopsis assectella (Bekkaoui and Thibout, 1993) or due to physical recognition by the parasitoids (Sandlan, 1980). Regardless of the mechanism, diamondback moth pupae without cocoons were still selected for oviposition by $D$. collaris, indicating that species without cocoons should still be included in a list of potential non-targets. Because pupae with intact cocoons did experience a higher attack rate, care should be taken to maintain the integrity of non-target pupal cocoons wherever possible.

\section{Conclusion}

In the first stages of host range testing, it is imperative to determine the widest possible host range under laboratory conditions rather than risk a false negative for a nontarget species that is in fact suitable. Withers and Browne (2004) suggest manipulating the physiological and informational state of the candidate, or its test environment, in ways that 
increase the parasitoid's motivation to oviposit in non-targets. Identifying the testing parameters that improve a parasitoid's motivation to oviposit in its normal host and then applying these to subsequent host specificity tests with non-target species relies on the assumption that whatever conditions make a parasitoid more likely to oviposit in its normal host will also make it more likely to attack a non-target species. This assumption might not always hold; for example, although Jenner et al. (2012) found that younger D. pulchellus females more effectively parasitized their leek moth hosts than older females, older $D$. pulchellus wasps were more likely to attack an unsuitable non-target species in the first few contacts (Jenner et al., 2014). Nonetheless, there was no effect of female age on overall parasitoid emergence from non-target species or on overall non-target mortality in nochoice tests (Jenner et al., 2014). Despite the imperfect match between conditions maximizing motivation to attack the host and the non-targets, the expressed host range of the parasitoid remained unchanged. Furthermore, identifying conditions that increase a parasitoid's motivation to attack the normal host can help eliminate from consideration any conditions not conducive to successful parasitism, thereby assisting in the identification of protocols that are more efficient (for example, the use of younger females rather than older ones can minimize the effort involved in rearing wasps to an older age when either age is equally likely to attack the host).

The results from this study were applied to design a host range testing protocol for D. collaris that maximizes both motivation to oviposit and testing efficiency with the following parameters: a diet of sucrose and pollen, three- to seven-day-old wasps, nontarget pupae presented without the presence of plant material, a 24-hour exposure length, and intact non-target pupal cocoons. 


\section{Figures}

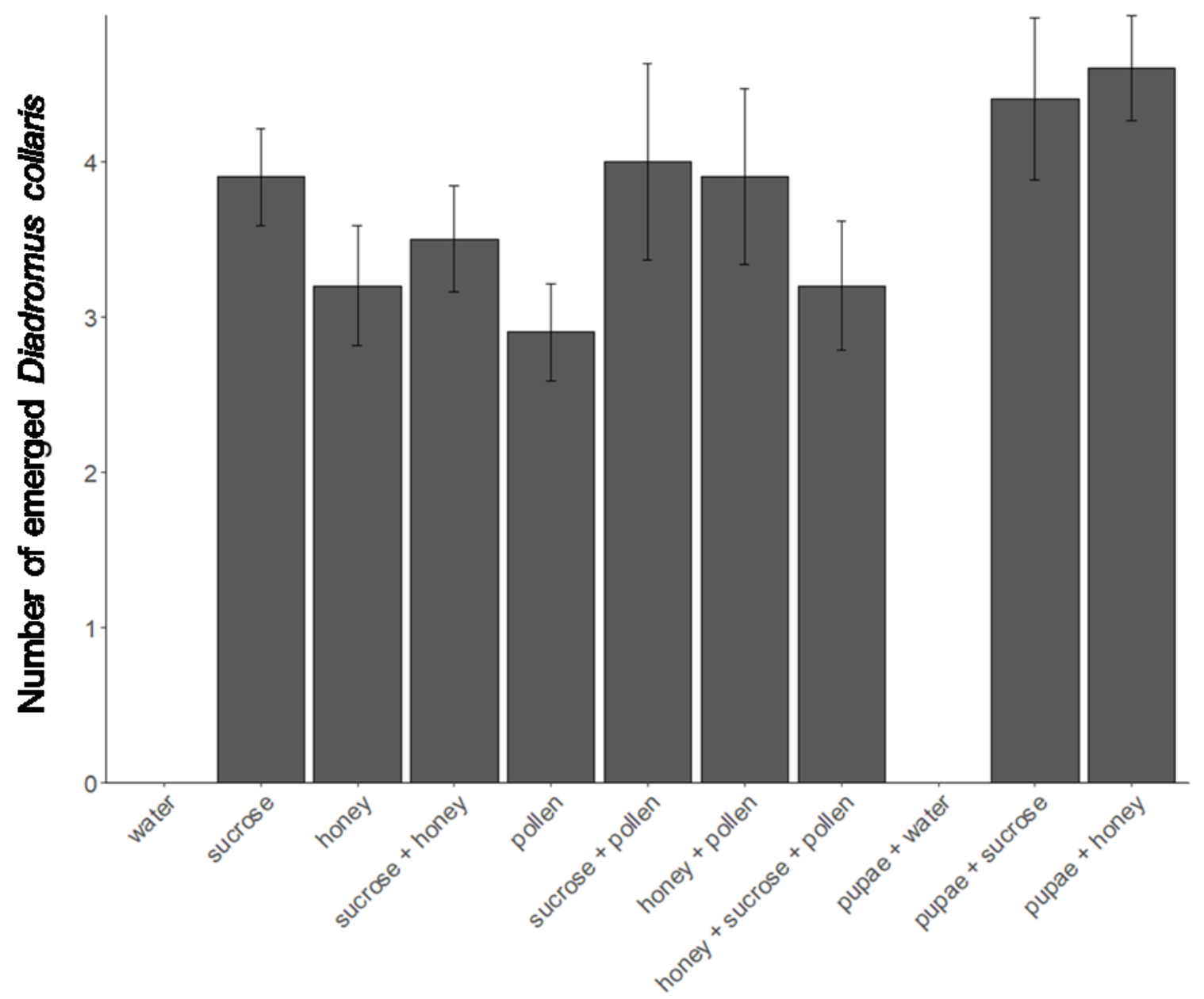

Figure 2.1: Offspring produced by female Diadromus collaris wasps fed for seven days on different diet treatments (Mean $\pm \mathrm{SE})(\mathrm{n}=10$ for each treatment). 


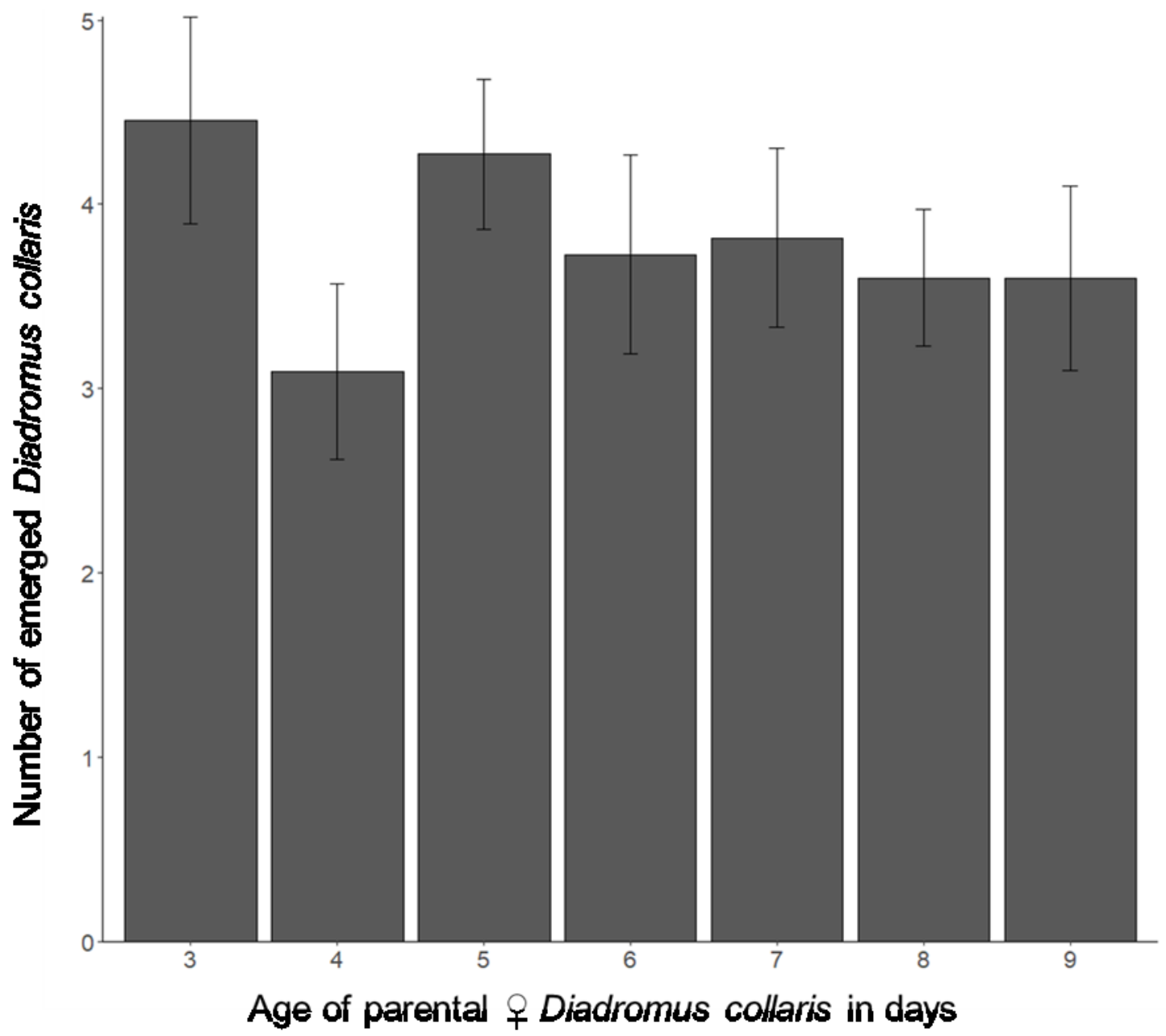

Figure 2.2: Offspring produced by female Diadromus collaris wasps of different ages $($ Mean \pm SE) $(n=11$ for each treatment $)$. 


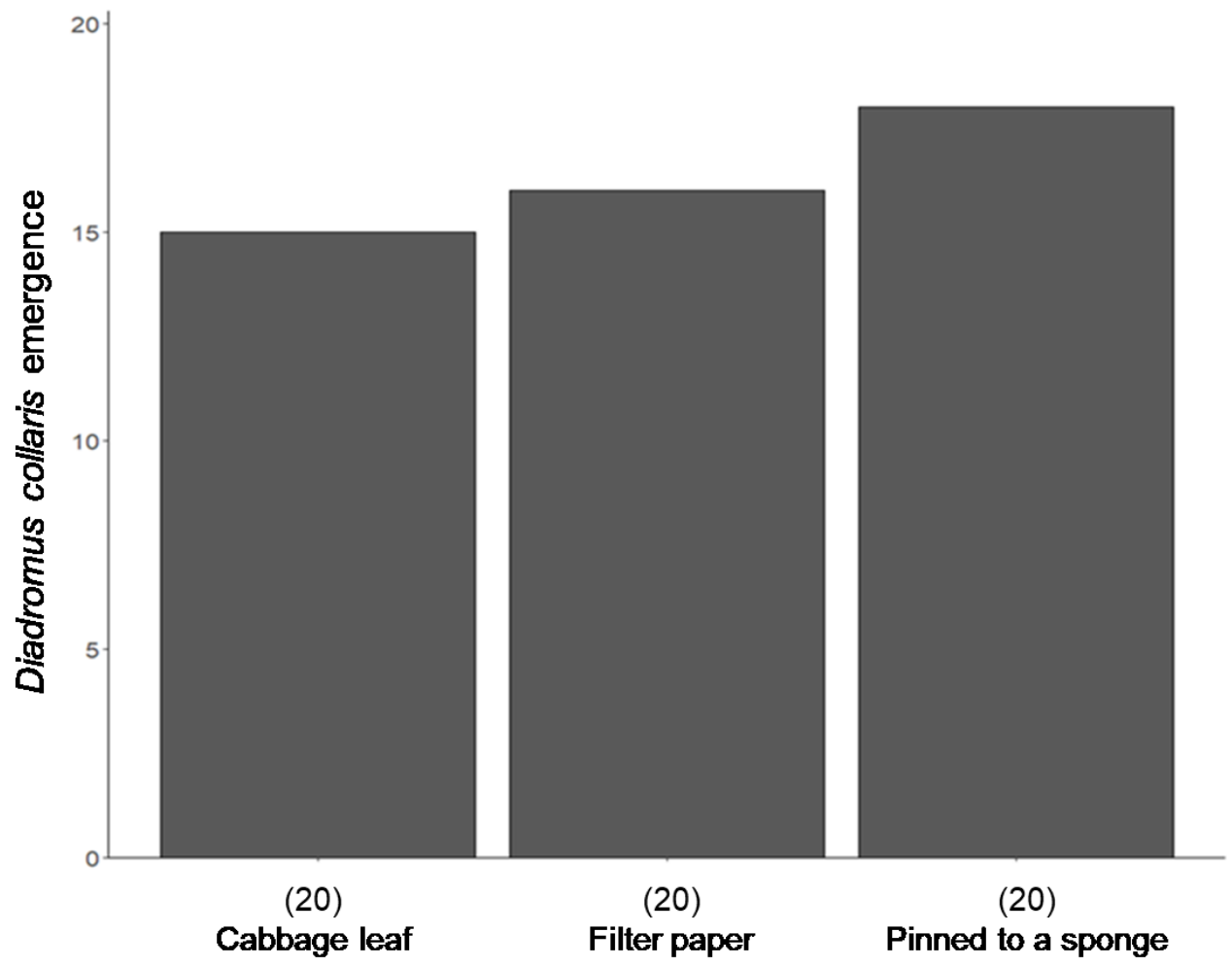

Figure 2.3: Number of Diadromus collaris that emerged from diamondback moth pupae presented on a cabbage plant, unsecured on a filter paper, or secured to a sponge with minuten pins. 


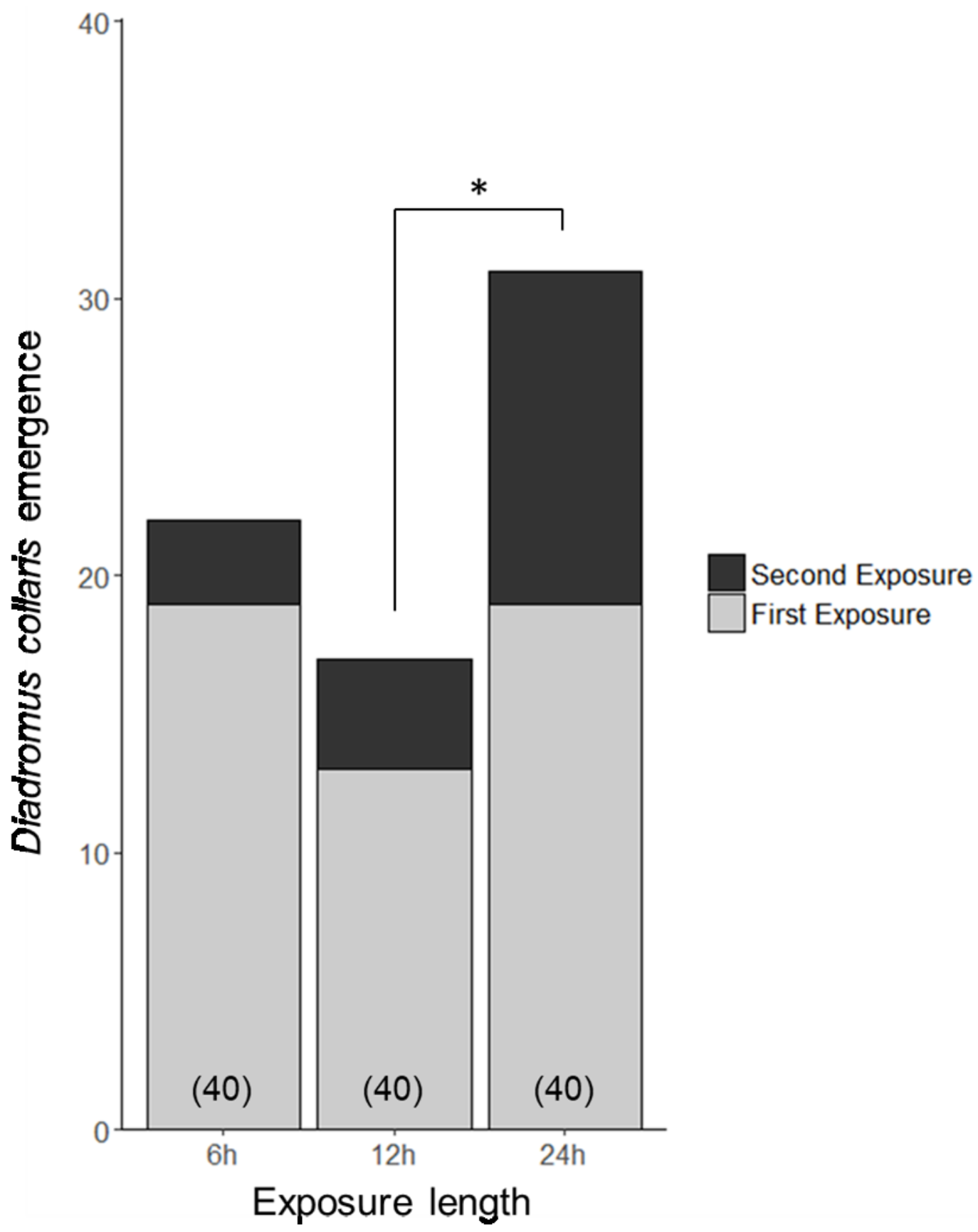

Figure 2.4: Number of Diadromus collaris offspring that emerged after two successive exposures to diamondback moth pupae for a period of 6 hours, 12 hours or 24 hours $(* \mathrm{p}<0.05)$. 

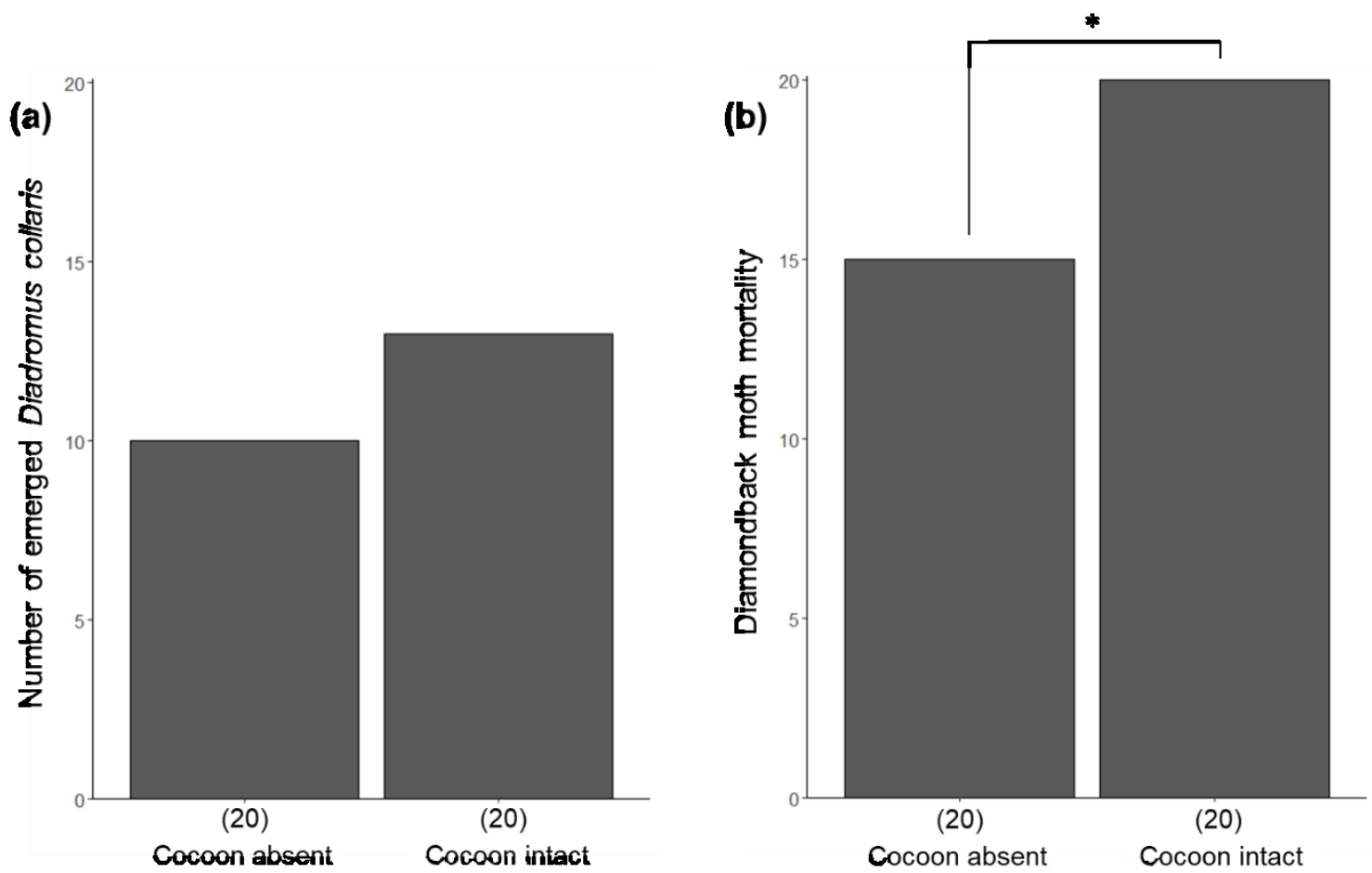

Figure 2.5: (a) Number of emerged Diadromus collaris (b) and diamondback moth mortality for diamondback moth pupae provided to $D$. collaris with their cocoons either intact or absent $(* \mathrm{p}<0.05)$. 


\section{Chapter 3: Determining the fundamental host range of Diadromus collaris. \\ Introduction}

The threat posed by invasive alien species to global biodiversity is second only to that of habitat destruction (Vitousek et al., 1997). Accidental introductions may disrupt essential ecosystem services; for instance, non-native arthropod pests can dramatically reduce productivity in both forestry and agricultural settings (Pimentel, 1986). Chemical insecticides are widely used to mitigate the negative effects of such invasions, but this solution may result in toxic effects to other species in the ecosystem, bioaccumulation in the food chain, or the evolution of resistance by pest populations. The release of a natural enemy from the pest's native range (i.e., importation biological control) can offer a sustainable and cost-effective alternative to the application of insecticides (Fisher et al., 1999); however, the establishment of any new biological control agent must be undertaken with caution. It is important to consider the potential for unintended consequences to species already present in the system, and in particular host range expansion to non-target native or beneficial species (van Lenteren et al., 2003). Ideal candidates for biological control are either monophagous, attacking the target pest species exclusively, or narrowly oligophagous, primarily attacking the target species but also related species to a lesser degree (van Lenteren et al., 2003). Biological control agents that establish and disperse widely are not likely to cause any negative effects to non-target species if they are host specific to the target pest.

The diamondback moth, Plutella xylostella (Linnaeus) (Lepidoptera: Plutellidae), is an invasive moth species that feeds on brassicaceous plants. Each year, the moth causes US\$ 4-5 billion in damages globally (Zalucki et al., 2012). Thought to originate from the 
Mediterranean (Harcourt, 1954; Talekar and Shelton, 1993), diamondback moth is now established worldwide wherever crucifers are grown, and is believed to have the most universal distribution of all Lepidoptera (Meyrick, 1928; Talekar and Shelton, 1993). Diamondback moth has an unrivaled ability to evolve insecticide resistance; it was the first species to develop resistance to DDT and to Bacillus thuringiensis Berliner serovar kurstaki (Bacillaceae) and in some areas is now resistant to all major classes of pesticides (Talekar and Shelton, 1993). In Canada, infestations occur periodically wherever canola, Brassica napus L. and B. rapa L. (Brassicaceae) is grown in the Prairies (Dosdall et al. 2008, 2011). In Alberta and Saskatchewan, outbreaks in 1985, 1995 and 2001 resulted in losses in the tens of millions of dollars (Madder and Stemeroff, 1988; WCCP, 1995; WCCP, 2001).

Worldwide, 135 species of natural enemies have been recorded to attack either the egg, larval or pupal stages of diamondback moth (Delvare, 2004). In Canada, three main parasitoid wasps contribute to diamondback moth mortality: Diadegma insulare (Cresson) (Hymenoptera: Ichneumonidae) and Microplitis plutellae (Muesbeck) (Hymenoptera: Braconidae) are both larval parasitoids, while Diadromus subtilicornis (Gravenhorst) (Hymenoptera: Ichneumonidae) is a pupal parasitoid (Braun et al., 2004; Sarfraz et al. 2005). Although these species can impose mortality rates of up to 58\% (Braun et al., 2004), they are ineffective at controlling diamondback moth below economic thresholds, and insecticides must routinely be applied.

Biological control is widely considered a critical component of diamondback moth management in areas where the native natural enemy community does not provide adequate control (Verkerk and Wright, 1996). Diadromus collaris (Gravenhorst) 
(Hymenoptera: Ichneumonidae), a solitary pupal endoparasitoid, is a candidate biological control agent for introduction into Canada. Diadromus collaris has a widespread natural distribution, with native populations throughout Europe, South Africa, and much of Asia (Furlong et al., 2013), and introduced populations occur in New Zealand, Australia, the Cook Islands, and Malaysia (Talekar and Shelton, 1993). The historical success of $D$. collaris in its native and introduced ranges (Chua and Ooi, 1986; Goodwin, 1979; Hamilton, 1979; Furlong et al., 2004; Liu et al., 2000) makes it a promising candidate for introduction into Canada, but before its release it is crucial to assess the parasitoid's host specificity.

There has been considerable progress towards a standardized procedure for host specificity testing, and although the particular protocols vary for each candidate, a general framework has emerged. First, literature records should be consulted to determine known hosts of the candidate agent and field surveys in its native region should be conducted, particularly where records are sparse (Sands and Van Driesche, 2004). These recorded hosts, and appropriate non-target species, should be provided to the candidate biological control agent for host specificity testing. Kuhlmann et al. (2006) proposed a comprehensive, multiple-criteria procedure for the determination of non-target species lists for host range testing of proposed arthropod biological control agents. These authors suggest that non-target species should be chosen based on phylogenetic relatedness to known hosts, ecological overlap, and safeguard considerations. Once the non-target species have been chosen, the next step is to determine the fundamental host range, i.e., the host species that are attacked and that support agent development in the lab (Onstad and McManus, 1996). The current and evolving set of species that are attacked in the field (i.e., 
the ecological host range) is generally narrower than the fundamental host range, so nontarget species that elicit a positive result in the laboratory should then be tested under conditions that mimic those found in nature (Barratt et al., 2010).

The aim of this study was to determine the fundamental host range of $D$. collaris, using a series of no-choice black box tests. Eight species of non-target lepidopteran pupae were exposed to female $D$. collaris to determine whether any were suitable for parasitoid development and/or whether exposure to D. collaris increased non-target mortality, possibly due to other factors such as host feeding or damage by the act of oviposition. An earlier study (Chapter 1) determined the test conditions required to maximize the parasitoid's motivation to oviposit, and thus reduce the potential that $D$. collaris would reject non-target species that are in fact suitable hosts.

\section{Materials \& Methods}

\section{Non-target host selection}

Host records of D. collaris are limited to three species (Yu et al., 2012). Although there are historical records of emergence from Lobesia botrana (Denis \& Schiffermüller) (Lepidoptera: Tortricidae) and the wasp has successfully been reared on Acrolepiopsis assectella (Zeller) (Lepidoptera: Glyphipterigidae), D. collaris is primarily known as a pupal parasitoid of diamondback moth. An initial list of non-targets (Table 3.1) was created using the criteria proposed by Kuhlmann et al. (2006), which in this case includes species that are phylogenetically related to the diamondback moth (i.e., those from the superfamily Yponomeutoidea), species that share an ecological overlap with the diamondback moth (i.e., feeding on Brassica spp. or in environments where brassicaceous plants are found), and safeguard species (i.e., weed biological control agents and rare species). Once this 
initial long list was created, it was reduced to a manageable level (Table 3.2) by filtering out species that are difficult to acquire or are less likely to be encountered by D. collaris.

Plutella armoraciae Busck (Lepidoptera: Plutellidae), Plutella porrectella (Linnaeus) (Lepidoptera: Plutellidae), Ypsolopha dentella (Fabricius) (Lepidoptera: Ypsolophidae), and A. assectella were selected for their close phylogenetic relationships with diamondback moth (Sohn et al., 2013) (refer to Figure A1 for a phylogram of the Yponomeutoidea). Pieris rapae (Linnaeus) (Lepidoptera: Pieridae) feeds on Brassica spp., while Athrips mouffetella (Linnaeus) (Lepidoptera: Gelechiidae) and Chrysoesthia sexguttella (Thunberg) (Lepidoptera: Gelechiidae) are common in agricultural settings where brassicaceous plants grow. Lobesiodes euphorbiana (Freyer) (Lepidoptera: Tortricidae) is an established biological control agent and thus a safeguard species. Additionally, it belongs to the same family as the known host $L$. botrana.

\section{Rearing of target and non-target hosts}

Diamondback moth were obtained from the Ottawa Research and Development Centre (ORDC), Agriculture and Agri-Food Canada (AAFC) (Ottawa, ON, Canada), where they have been kept in continuous culture reared on Brassica oleracea Linnaeus var. capitata since 2016. Non-target hosts were either field-collected or obtained from continuously reared cultures. $P$. armoraciae was obtained from continuous culture at the Agassiz Research and Development Centre, AAFC, while P. porrectella and A. assectella were obtained from cultures at the ORDC. The remaining five species were field collected and reared on their natural plant material from May to August 2018. Y. dentella, A. mouffetella, C. sexguttella, and P. rapae were collected on the Central Experimental Farm

(Ottawa, ON), at Wise Acres Organic farm (Centreville, ON, Canada) and at the Waratah 
Downs Organic Farm (Perth, ON, Canada). L. euphorbiana and its host plant were collected from Guelph, ON. All target and non-target cultures were monitored daily and only newly formed pupae were used for testing.

Individuals of non-target species collected directly from nature may already be parasitized or infected by disease. Ideally, all field collections are reared for one complete generation prior to host range testing to eliminate the potential for contamination. In the case of $P$. rapae, a temporary culture was created, and $2^{\text {nd }}$ or $3^{\text {rd }}$ generation pupae were used for host range testing. Laboratory cultures of $Y$. dentella, A. mouffetella, $C$. sexguttella, and L. euphorbiana proved difficult to establish. For these species, larvae were collected in early instars wherever possible to reduce the chances of parasitism precollection, although all four species did experience low levels of parasitism before they were collected for use in experiments. Control non-target pupae not exposed to D. collaris were particularly important for these field collected samples, in order to determine natural mortality rates.

With the exception of $A$. mouffetella, non-target pupae and target diamondback moth pupae were presented without plant material to prevent conditioning (although pupae may still have carried the scent of plant material on them). A. mouffetella generally pupated on small branches, and interwove their cocoons with bark, which made removal difficult without destroying the woven cocoon. These pupae were presented with minimal plant material, which sometimes included a portion of the wooden branch but never leaf material.

Rearing and preparation of Diadromus collaris

An initial population of $D$. collaris was obtained from Delémont, Switzerland in 2016. A culture was maintained at the ORDC AAFC containment facility, and new 
individuals from the same population were added in 2017 and 2018. Female wasps were transferred upon emergence into a clear plastic dish $(101 \times 54 \mathrm{~mm}$, Semadeni AG, Ostermundigen, Switzerland) and housed in groups of 6-10. An equal number of males was added and allowed to mate for 48 hours, after which time they were removed. Wasps were provided with a dental wick soaked in $10 \%$ sucrose and pollen paste, which was changed every 48 hours. All wasps used for non-target testing were between three and seven days old. Throughout testing, the rearing room temperature was maintained at $21^{\circ} \mathrm{C} \pm 1{ }^{\circ} \mathrm{C}$ on a 16:8 L:D photoperiod cycle with $54 \pm 19 \%$ relative humidity.

\section{No-choice non-target testing}

To determine whether any non-target species are suitable hosts for D. collaris and/or whether $D$. collaris affects non-target mortality, female $D$. collaris were exposed to a single non-target pupa for a period of 24 hours. A 24-hour exposure eliminated the potential for a "time-of-day effect", and preliminary experiments showed that a 24-hour exposure elicits the highest $D$. collaris emergence from diamondback moth pupae. Both target and non-target pupae were secured on a sponge with minuten pins to facilitate oviposition. Tests took place in clear plastic dishes $(90 \times 25 \mathrm{~mm}$, Semadeni AG, Ostermundigen, Switzerland), and wasps were provided with $10 \%$ sucrose and pollen paste throughout the test period. As a negative control, a non-target pupa reared under the same conditions but not exposed to $D$. collaris was used to ensure that non-emergence was in fact due to parasitism and not some other factor. As a simultaneous positive control, another female $D$. collaris from the same cohort was exposed to a diamondback moth pupa to determine whether failure to attack was due to poor parasitoid quality and/or substandard conditions. As a second positive control, to prevent non-viable wasps from biasing 
results, each $D$. collaris test wasp was provided with a diamondback moth pupa for 24 hours after its exposure to the non-target (see Figure 3.1 for a schematic of exposures). Wasps were then preserved in ethanol for use as voucher specimens. Pupae of target and non-target species were maintained in the controlled conditions described above until the emergence of wasps or moths. If no D. collaris offspring emerged from the simultaneous positive controls for a particular cohort, these replicates were not included in statistical analysis. If $D$. collaris did not emerge from the subsequent exposure positive control, the parental wasp was considered non-viable and test results for these individuals were also discarded.

\section{Statistical analyses}

A chi-square test of association was run for each species to determine whether there was a difference in the emergence of Lepidoptera exposed to $D$. collaris and the emergence from control pupae not exposed to $D$. collaris. For non-target species that were suitable for D. collaris development, chi-square tests were run to determine whether D. collaris emergence was significantly different between non-target pupae and the simultaneous diamondback moth control pupae. All data analyses were completed using R-studio version R 3.4.4 (R Core Team, 2017).

\section{Results}

Of the eight non-target species, three, $P$. armoraciae, $P$. porrectella, and $A$. assectella, were suitable hosts for $D$. collaris development. Parasitoids emerged from $P$. armoraciae in $29 \%$ of exposures, which was significantly lower than the $73 \%$ parasitoid emergence from the diamondback moth pupae exposed to D. collaris concurrently $\left(\chi^{2}=\right.$ 
16.672, $\mathrm{p}<0.001$ ) (Figure 3.2). Likewise, A. assectella also had significantly lower wasp emergence than its corresponding diamondback moth controls, with $37 \%$ and $73 \% D$. collaris emergence respectively $\left(\chi^{2}=8.148, \mathrm{p}=0.004\right)$. There was no significant difference in D. collaris emergence from $P$. porrectella and diamondback moth controls $(66 \%$ emergence vs $63 \%$ emergence; $\chi^{2}=0.057, p=0.811$ ).

Plutella porrectella and P. armoraciae had significantly reduced emergence after D. collaris exposure compared to pupae that were not exposed to wasps $\left(\chi^{2}=50.113\right.$, $\mathrm{p}<0.001 ;$ and $\chi^{2}=26.438, \mathrm{p}<0.001 ;$ respectively). Only $8 \%$ of $P$. porrectella moths emerged after parasitoid exposure compared to $85 \%$ of the non-exposed control pupae, and only $3 \%$ of parasitoid-exposed P. armoraciae emerged compared to $63 \%$ of control pupae (Figure 3.3). Acrolepiopsis assectella also had significantly reduced emergence after $D$. collaris exposure $\left(\chi^{2}=19.217, \mathrm{p}<0.001\right)$, although the difference was not as pronounced: $33 \%$ of A. assectella were still able to develop and emerge despite exposure to the parasitoid, compared to $82 \%$ of controls. Diadromus collaris-exposed pupae for the remaining five species did not exhibit any significant difference in moth emergence compared to nonexposed control pupae (Ypsolopha dentella $\left(\chi^{2}=2.149, \mathrm{p}=0.143\right)$, Athrips mouffetella $\left(\chi^{2}\right.$ $=1.729, \mathrm{p}=0.189)$, Chrysoesthia sexguttella $\left(\chi^{2}=0.037, \mathrm{p}=0.847\right)$, Pieris rapae $\left(\chi^{2}=0.130\right.$, $\mathrm{p}=0.719)$, Lobesiodes euphorbiana $\left.\left(\chi^{2}=1.282, \mathrm{p}=0.258\right)\right)$.

Although the host range testing was largely allowed to proceed without direct observation (black box trials), the first few minutes of most replicates were observed. While no official metrics were tested, P. porrectella, P. armoraciae, A. assectella and $Y$. dentella were observed to elicit drumming behavior in D. collaris. This type of antennal tapping is used by many species to examine a potential host before oviposition (Vinson, 
1976). In the case of $Y$. dentella, ovipositor insertion was never observed, although it is possible that over the course of the test period oviposition may have occurred without an observer present.

\section{Discussion}

The fundamental host range of Diadromus collaris includes three of the eight nontarget species tested, Plutella armoraciae, Plutella porrectella, and Acroplepiposis assectella. Diadromus collaris emerged from P. porrectella in $66 \%$ of its exposures, from P. armoraciae in $29 \%$, and from A. assectella in 37\% (Figure 3.2).

Exposure to $D$. collaris resulted in increased mortality for pupae of $P$. armoraciae, P. porrectella and A. assectella (Figure 3.3). For the remaining five species, Ypsolopha dentella, Athrips mouffetella, Chrysoesthia sexguttella, Pieris rapae, and Lobesiodes euphorbiana, exposure to D. collaris did not result in any significant difference in moth emergence compared to control pupae.

While these no-choice tests do not intrinsically test host preference, they offer insight into host preferences when the parasitoid emergence rate from non-targets is compared to the emergence rate from diamondback moth controls. A comparison of nontarget mortality in parasitoid-exposed pupae to the mortality of non-exposed control pupae can provide additional insight, since parasitoid exposure can also result in host mortality without successful reproduction, either through destructive host-feeding, mutilation from ovipositor insertion, or eggs that fail to develop to completion inside their hosts (Abram et al., 2016) For $P$. porrectella, a congener of diamondback moth, there was no significant difference in wasp emergence between the non-target pupae and the diamondback moth controls. Parasitoid-exposed $P$. porrectella pupae also experienced a high mortality rate, 
with only $8 \%$ moth emergence compared to $85 \%$ emergence from non-exposed control pupae; these results indicate a high level of suitability for $D$. collaris development. For $P$. armoraciae, another congener of diamondback moth, wasps emerged from diamondback moth controls 2.8 times more frequently than from the non-targets. Interestingly though, P. armoraciae moth emergence from parasitoid-exposed pupae was only $3 \%$, while nonexposed $P$. armoraciae controls exhibited $63 \%$ emergence. Exposure to $D$. collaris resulted in the highest mortality in $P$. armoraciae, but this species exhibited the lowest wasp emergence rate. Wasps emerged only half as often from the known host $A$. assectella as from diamondback moth controls, and non-target mortality was lower than from the either P. porrectella or P. armoraciae (33\% A. assectella emergence from parasitoid-exposed pupae, compared to $82 \%$ emergence from non-exposed control pupae). This suggests that while $P$. armoraciae may be preferred over $A$. assectella for oviposition, A. assectella is in fact more suitable for $D$. collaris development. Of course, without observing parasitoid behavior throughout exposures and dissecting pupae to confirm whether or not oviposition did take place, it is not possible to confirm whether differences in either parasitoid or moth emergence resulted from variation in the frequency of attack or from variation in the host's immune response.

Regardless, it is apparent from these results that the fundamental host range of $D$. collaris includes species that are closely related to diamondback moth, rather than those which are just ecologically or morphologically similar. Plutella porrectella and Plutella armoraciae belong to the same genus as diamondback moth, while $A$. assectella belongs to the family Glyphipterigidae, which is the most closely related family to the Plutellidae (Sohn et al., 2013) (Figure A1). In terms of ecological similarity, P. rapae, a butterfly 
species which develops on brassicaceous plants, did not induce parasitism despite the possible presence of sulphur-containing volatiles. The role of semiochemicals in the foraging behavior of $D$. collaris is unclear; an electroantennogram study showed that $D$. collaris is responsive to the volatiles from cabbage plants (Lecomte and Pouzat, 1985), but in a wind tunnel study the parasitoid did not respond to herbivore-induced damage in cabbage plants (Charleston et al., 2006). Either way, P. rapae did not induce parasitism despite the possible presence of brassicaceous volatiles. The morphologically similar $A$. mouffetella also did not exhibit a reduction in moth emergence resulting from parasitoid exposure. Thus, it seems clear that phylogenetically related species are the most at risk for non-target $D$. collaris parasitism. Moreover, the results indicate a relatively narrow host range given that $Y$. dentella, which belongs to the next most closely related family (Ypsolophidae) (Sohn et al., 2013), did not exhibit significantly increased mortality resulting from parasitoid exposure. Yypsolopha dentella did occasionally elicit drumming behavior in $D$. collaris, but ovipositor insertion was never observed. Since the tests were largely allowed to proceed without observation, it is certainly possible that over the course of the test period, as the acceptance threshold decreased, oviposition may have occurred without an observer present. Notwithstanding, if oviposition did occur, no D. collaris were able to complete development in these hosts and there was no significant reduction in moth emergence. This suggests that the fundamental host range of $D$. collaris is likely limited to the Plutellidae and Glyphipterigidae.

The results from this study have some important implications for the potential introduction of $D$. collaris into Canada. First and foremost, further testing of additional non-target species is required before the parasitoid is released. Given that the results from 
this study demonstrate the importance of phylogenetic relatedness, more native species from the family Glyphipterigidae should be tested to determine to what degree these microlepidopterans are suitable hosts. Of particular interest is the sub-family Glyphipteriginae, since several of the species in this sub-family are common in agricultural settings. These species are difficult to obtain because their larvae spend the majority of their lives feeding internally in their hosts (Cyperaceae) until they exit to pupate in leaf axils, but the indispensability of this work is now apparent. There are also two other North American species in the subfamily Acrolepiinae (Acrolepiopsis incertella (Chambers) and Acrolepiopsis heppneri (Gaedike), though they would be unlikely to be parasitized in the field since their host plants, Smilax spp. (Smilacaceae), grow in forested areas and along river banks where there is little ecological overlap with the habitat of diamondback moth. Another species that may warrant testing is the hop tree ermine moth, Prays atomocella (Dyar), which belongs to the family Praydidae (a more distantly related family in the Yponomeutoidea) and is listed by COSEWIC (Committee on the Status of Endangered Wildlife in Canada) as endangered. The larvae feed inside shoots of Ptelea trifoliata L. (Rutaceae) and are thus are unlikely to be attractive to the parasitoid, but special consideration should be given to this safeguard species. The non-native species Prays fraxinella Bjerkander (Praydidae), which mines the leaves of ash, Fraxinus excelsior L. and Fraxinus ornus L. (Oleaceae), may be a suitable surrogate species. In terms of other species of Plutellidae, less is known about their host range and life-history traits, though several are found on brassicaceous plants. Although these species are not considered to be of essential economic or ecological importance (Jean-François Landry, personal communication in Jenner, 2009), it would still be worthwhile to attempt to obtain samples 
for testing before release of $D$. collaris in Canada. Finally, there are also historical records of an association between D. collaris and Lobesia botrana in Germany (Meyer, 1934; Telenga, 1934), although the validity of identifications prior to 1950 can be questionable (Furlong et al., 2013). Lobesiodes euphorbiana, which belongs to the same family (Tortricidae), was not a suitable host for $D$. collaris and exposure to the parasitoid did not result in a reduction in moth emergence. Additionally, host range testing for Diadromus pulchellus, a parasitoid of $A$. assectella that is closely related to $D$. collaris, determined that L. botrana is not a suitable host for development, nor did the moth exhibit any increase in mortality after parasitoid exposure (Jenner et al., 2014). Nevertheless, no-choice tests are underway at the Centre for Agriculture Bioscience International (CABI) in Delémont Switzerland to investigate the possibility that $D$. collaris is able to parasitize L. botrana although its congener did not. If $L$. botrana is indeed found to be a suitable host, further research into species belonging to the family Tortricidae will be required.

Of the species tested in this study, $P$. porrectella is non-native and A. assectella is in fact invasive; therefore, a host range expansion to these species is not a substantial cause for alarm. While $P$. armoraciae is a native species, the results from this study indicate that it is a less suitable host than the diamondback moth. Moving forward, it will be necessary to clarify the host preference of $D$. collaris in order to more accurately assess the risk to native non-target species. Although $P$. armoraciae belongs to the parasitoid's fundamental host range (i.e., it is a suitable host in the laboratory), it is well established that non-natural conditions can artificially inflate the rate of attack on less-preferred non-target species (e.g., Cameron and Walker, 1997; Morehead and Feener, 2000; Froud and Stevens, 2002; Haye et al., 2005). Without the presence of plant material or previous host experience, parasitoids 
are more likely to oviposit in non-preferred hosts (Withers and Browne, 2004). Confinement over long exposures can artificially increase ovipositional events, since it is common for a parasitoid's threshold for oviposition to decrease as egg load builds (Van Driesche and Murray, 2004). Under natural conditions, if insects deem a host unsuitable, they are free to disperse rather than depositing eggs into non-preferred hosts. Additionally, the host-searching phase of foraging is a key first step that is eliminated when hosts are provided to the parasitoid (Van Driesche and Murray, 2004) for host specificity testing. If the biological control agent is rarely in contact with a non-target species, either because the searching habitat does not overlap or the non-target kairomones are not attractive, then even highly suitable species in the fundamental host range are less at risk. All of these factors can result in an ecological host range, or realized host range, that is narrower than the fundamental host range. For example, no-choice host range tests of Diadromus pulchellus determined that diamondback moth was a highly suitable host (Jenner et al., 2014) but 12 years of post-release monitoring has resulted in only one instance of $D$. pulchellus emergence from diamondback moth sentinels (Mason et al., 2013). This suggests a much higher level of host specificity than was estimated experimentally using no-choice tests.

Given the irreversible nature of biological control introductions it is important to take a cautious approach to host specificity testing. The consistent rejection of a host species in a no-choice test provides convincing evidence that the non-target is not at risk for host range expansion, as long as the motivation to oviposit of the candidate biological control agent is maximized and the tests sufficiently replicated (Van Driesche and Murray, 2004). It is for this reason that no-choice tests are preferred by regulators for the 
determination of host specificity, at least as a first step. Then, to assess host preferences with greater accuracy, non-targets that have been identified as suitable or at risk through no-choice small arena tests can be the focus of further behavioral studies and choice tests where both the target and non-target species are presented to the candidate. From there, large arena tests with plant material and/or field tests in the region of origin can be conducted to provide a clearer assessment of the risk for host range expansion. This stepwise hierarchical approach to host range testing for candidate biological control agents (Figure 3.4) is widely recommended, since it provides a cautious approach that minimizes false negatives while promoting safe forms of biological control (van Lenteren et al., 2006). Initial test lists of potential non-target species may be very long, and it is impractical and unnecessary to conduct all steps for each non-target species on the initial list. By conducting preliminary no-choice tests, we can confidently eliminate some non-target species as potential hosts and highlight suitable or at-risk species that require further testing.

In conclusion, this study of the fundamental host range of $D$. collaris provides an important starting place in the determination of the parasitoid's host specificity. While it is now clear that $D$. collaris can successfully parasitize some non-target Plutellidae and Glyphipterigidae, further research is required to determine how severe these non-target effects may be. The results from this study therefore provide direction to appropriate nontarget species that have yet to be tested, and indicate that $P$. armoraciae, $P$. porrectella, and $A$. assectella, should be further evaluated using choice and large arena tests to assess more precisely the host preferences of $D$. collaris. 


\section{Tables}

Table 3.1: Preliminary non-target test list for Diadromus collaris (Hymenoptera: Ichneumonidae).

\begin{tabular}{|c|c|c|}
\hline Insect species [Family] & Host plant [Family] $^{1}$ & Criteria for selection \\
\hline $\begin{array}{l}\text { Target } \\
\text { Plutella xylostella (Linnaeus) } \\
\text { [Plutellidae] }\end{array}$ & $\begin{array}{l}\text { Brassica spp. } \\
\text { [Brassicaceae] }\end{array}$ & - \\
\hline \multicolumn{3}{|l|}{ Non-targets } \\
\hline $\begin{array}{l}\text { Plutella armoraciae Busck } \\
\text { [Plutellidae] }\end{array}$ & $\begin{array}{l}\text { Brassica juncea } \\
\text { (Linnaeus) Czernajew } \\
\text { [Brassicaceae] }\end{array}$ & $\begin{array}{l}\text { Phylogenetic affinity } \\
\text { Ecological overlap } \\
\text { Morphological similarity }\end{array}$ \\
\hline $\begin{array}{l}\text { Plutella porrectella (Linnaeus) } \\
\text { [Plutellidae] }\end{array}$ & $\begin{array}{l}\text { Hesperis matronalis } \\
\text { Linnaeus } \\
\text { [Brassicaceae] }\end{array}$ & $\begin{array}{l}\text { Phylogenetic affinity } \\
\text { Ecological overlap } \\
\text { Morphological similarity }\end{array}$ \\
\hline $\begin{array}{l}\text { Rhigognostis } \\
\text { interrupta (Walsingham) } \\
\text { [Plutellidae] }\end{array}$ & Unknown & Phylogenetic affinity \\
\hline $\begin{array}{l}\text { Acrolepiopsis assectella (Zeller) } \\
\text { [Glyphipterigidae] }\end{array}$ & $\begin{array}{l}\text { Allium porrum Linnaeus } \\
\text { [Alliaceae] }\end{array}$ & $\begin{array}{l}\text { Previous host record } \\
\text { Phylogenetic affinity } \\
\text { Ecological overlap } \\
\text { Morphological similarity }\end{array}$ \\
\hline $\begin{array}{l}\text { Diploschizia impigritella } \\
\text { (Clemens) [Glyphipterigidae] }\end{array}$ & $\begin{array}{l}\text { Cyperus esculentus } \\
\text { Linnaeus [Cyperaceae] }\end{array}$ & $\begin{array}{l}\text { Phylogenetic affinity } \\
\text { Ecological overlap }\end{array}$ \\
\hline $\begin{array}{l}\text { Ypsolopha canariella } \\
\text { (Walsingham) [Ypsolophidae] }\end{array}$ & $\begin{array}{l}\text { Lonicera spp. } \\
\text { [Caprifoliaceae] } \\
\text { Salix spp. [Salicaceae] }\end{array}$ & $\begin{array}{l}\text { Phylogenetic affinity } \\
\text { Ecological overlap }\end{array}$ \\
\hline $\begin{array}{l}\text { Ypsolopha dentella (Fabricius) } \\
\text { [Ypsolophidae] }\end{array}$ & $\begin{array}{l}\text { Lonicera spp. } \\
\text { [Caprifoliaceae] }\end{array}$ & $\begin{array}{l}\text { Phylogenetic affinity } \\
\text { Ecological overlap }\end{array}$ \\
\hline $\begin{array}{l}\text { Argyresthia annettella Busck } \\
\text { [Argyresthiidae] }\end{array}$ & $\begin{array}{l}\text { Juniperus communis } \\
\text { Linnaeus } \\
\text { [Cupressaceae] }\end{array}$ & $\begin{array}{l}\text { Phylogenetic affinity } \\
\text { Morphological similarity }\end{array}$ \\
\hline $\begin{array}{l}\text { Argyresthia calliphanes Meyrick } \\
\text { [Argyresthiidae] }\end{array}$ & Alnus spp. [Betulaceae] & Phylogenetic affinity \\
\hline $\begin{array}{l}\text { Argyresthia goedartella } \\
\text { (Linnaeus) [Argyresthiidae] }\end{array}$ & $\begin{array}{l}\text { Alnus spp. [Betulaceae] } \\
\text { Betula spp. [Betulaceae] }\end{array}$ & Phylogenetic affinity \\
\hline
\end{tabular}




\begin{tabular}{|c|c|c|}
\hline $\begin{array}{l}\text { Leucoptera albella (Chambers) } \\
\text { [Lyonetiidae] }\end{array}$ & $\begin{array}{l}\text { Populus deltoides } \\
\text { Bartram ex Marshall } \\
\text { [Salicaceae] }\end{array}$ & Phylogenetic affinity \\
\hline $\begin{array}{l}\text { Bedellia somnulentella (Zeller) } \\
\text { [Bedellidae] }\end{array}$ & $\begin{array}{l}\text { Calystegia spp., } \\
\text { Convolvulus spp., Ipomoea } \\
\text { spp. [Convolvulaceae] }\end{array}$ & $\begin{array}{l}\text { Phylogenetic affinity } \\
\text { Ecological overlap }\end{array}$ \\
\hline $\begin{array}{l}\text { Athrips mouffetella (Linnaeus) } \\
\text { [Gelechiidae] }\end{array}$ & $\begin{array}{l}\text { Lonicera spp. Linnaeus } \\
\text { [Caprifoliaceae] }\end{array}$ & $\begin{array}{l}\text { Ecological overlap } \\
\text { Morphological similarity }\end{array}$ \\
\hline $\begin{array}{l}\text { Lobesia botrana (Denis \& } \\
\text { Schiffermüller) [Tortricidae] }\end{array}$ & $\begin{array}{l}\text { Vitis vinifera Linnaeus } \\
\text { [Vitaceae] }\end{array}$ & Previous host record \\
\hline $\begin{array}{l}\text { Chrysoesthia sexguttella } \\
\text { (Thunberg) [Gelechiidae] }\end{array}$ & $\begin{array}{l}\text { Chenopodium album } \\
\text { Linnaeus [Amaranthaceae] }\end{array}$ & Ecological overlap \\
\hline $\begin{array}{l}\text { Chrysoesthia drurella (Fabricius) } \\
\text { [Gelechiidae] }\end{array}$ & $\begin{array}{l}\text { Chenopodium album } \\
\text { Linnaeus [Amaranthaceae] }\end{array}$ & Ecological overlap \\
\hline Pieris rapae (Linnaeus) [Pieridae] & $\begin{array}{l}\text { Brassica spp. } \\
\text { [Brassicaceae] }\end{array}$ & Ecological overlap \\
\hline $\begin{array}{l}\text { Mamestra configurata Walker } \\
\text { [Noctuidae] }\end{array}$ & $\begin{array}{l}\text { Brassica spp. } \\
\text { [Brassicaceae] }\end{array}$ & Ecological overlap \\
\hline $\begin{array}{l}\text { Prays atomocella (Dyar) } \\
\text { [Praydidae] }\end{array}$ & $\begin{array}{l}\text { Ptelea trifoliata Linnaeus } \\
\text { [Rutaceae] }\end{array}$ & $\begin{array}{l}\text { Phylogenetic affinity } \\
\text { Safeguard species }\end{array}$ \\
\hline $\begin{array}{l}\text { Lobesiodes euphorbiana (Freyer) } \\
\text { [Tortricidae] }\end{array}$ & $\begin{array}{l}\text { Euphorbia esula Linnaeus } \\
\text { [Euphorbiaceae] }\end{array}$ & $\begin{array}{l}\text { Safeguard species } \\
\text { Phylogenetic affinity }\end{array}$ \\
\hline
\end{tabular}

\footnotetext{
${ }^{1}$ The host plant information in this table was obtained from a variety of sources, including primary literature, bugguide.net, UKmoths.org, butterfliesandmoths.org, and personal communications with Jean-François Landry, AAFC Ottawa.
} 
Table 3.2: Non-target test list for Diadromus collaris (Hymenoptera: Ichneumonidae).

\begin{tabular}{|c|c|c|}
\hline Insect species [Family] & 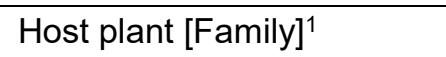 & Criteria for selection \\
\hline $\begin{array}{l}\text { Target } \\
\text { Plutella xylostella (Linnaeus) } \\
\text { [Plutellidae] }\end{array}$ & $\begin{array}{l}\text { Brassica spp. } \\
\text { [Brassicaceae] }\end{array}$ & - \\
\hline \multicolumn{3}{|l|}{ Non-targets } \\
\hline $\begin{array}{l}\text { Plutella armoraciae Busck } \\
\text { [Plutellidae] }\end{array}$ & $\begin{array}{l}\text { Brassica juncea } \\
\text { (Linnaeus) Czernajew } \\
\text { [Brassicaceae] }\end{array}$ & $\begin{array}{l}\text { Phylogenetic affinity } \\
\text { Ecological overlap } \\
\text { Morphological similarity }\end{array}$ \\
\hline $\begin{array}{l}\text { Plutella porrectella (Linnaeus) } \\
\text { [Plutellidae] }\end{array}$ & $\begin{array}{l}\text { Hesperis matronalis } \\
\text { Linnaeus } \\
\text { [Brassicaceae] }\end{array}$ & $\begin{array}{l}\text { Phylogenetic affinity } \\
\text { Ecological overlap } \\
\text { Morphological similarity }\end{array}$ \\
\hline $\begin{array}{l}\text { Acrolepiopsis assectella (Zeller) } \\
\text { [Glyphipterigidae] }\end{array}$ & $\begin{array}{l}\text { Allium porrum Linnaeus } \\
\text { [Alliaceae] }\end{array}$ & $\begin{array}{l}\text { Previous host record } \\
\text { Phylogenetic affinity } \\
\text { Ecological overlap } \\
\text { Morphological similarity }\end{array}$ \\
\hline $\begin{array}{l}\text { Ypsolopha dentella (Fabricius) } \\
\text { [Ypsolophidae] }\end{array}$ & $\begin{array}{l}\text { Lonicera spp. } \\
\text { [Caprifoliaceae] }\end{array}$ & $\begin{array}{l}\text { Phylogenetic affinity } \\
\text { Ecological overlap }\end{array}$ \\
\hline $\begin{array}{l}\text { Athrips mouffetella (Linnaeus) } \\
\text { [Gelechiidae] }\end{array}$ & $\begin{array}{l}\text { Lonicera spp. Linnaeus } \\
\text { [Caprifoliaceae] }\end{array}$ & $\begin{array}{l}\text { Ecological overlap } \\
\text { Morphological similarity }\end{array}$ \\
\hline $\begin{array}{l}\text { Chrysoesthia sexguttella } \\
\text { (Thunberg) [Gelechiidae] }\end{array}$ & $\begin{array}{l}\text { Chenopodium album } \\
\text { Linnaeus [Amaranthaceae] }\end{array}$ & Ecological overlap \\
\hline Pieris rapae (Linnaeus) [Pieridae] & $\begin{array}{l}\text { Brassica spp. } \\
\text { [Brassicaceae] }\end{array}$ & Ecological overlap \\
\hline $\begin{array}{l}\text { Lobesiodes euphorbiana (Freyer) } \\
\text { [Tortricidae] }\end{array}$ & $\begin{array}{l}\text { Euphorbia esula Linnaeus } \\
\text { [Euphorbiaceae] }\end{array}$ & $\begin{array}{l}\text { Safeguard species } \\
\text { Phylogenetic affinity }\end{array}$ \\
\hline
\end{tabular}

${ }^{1}$ The host plant information in this table was obtained from a variety of sources, including: primary literature, bugguide.net, UKmoths.org, butterfliesandmoths.org, and personal communications with Jean-François Landry, AAFC Ottawa. 


\section{Figures}
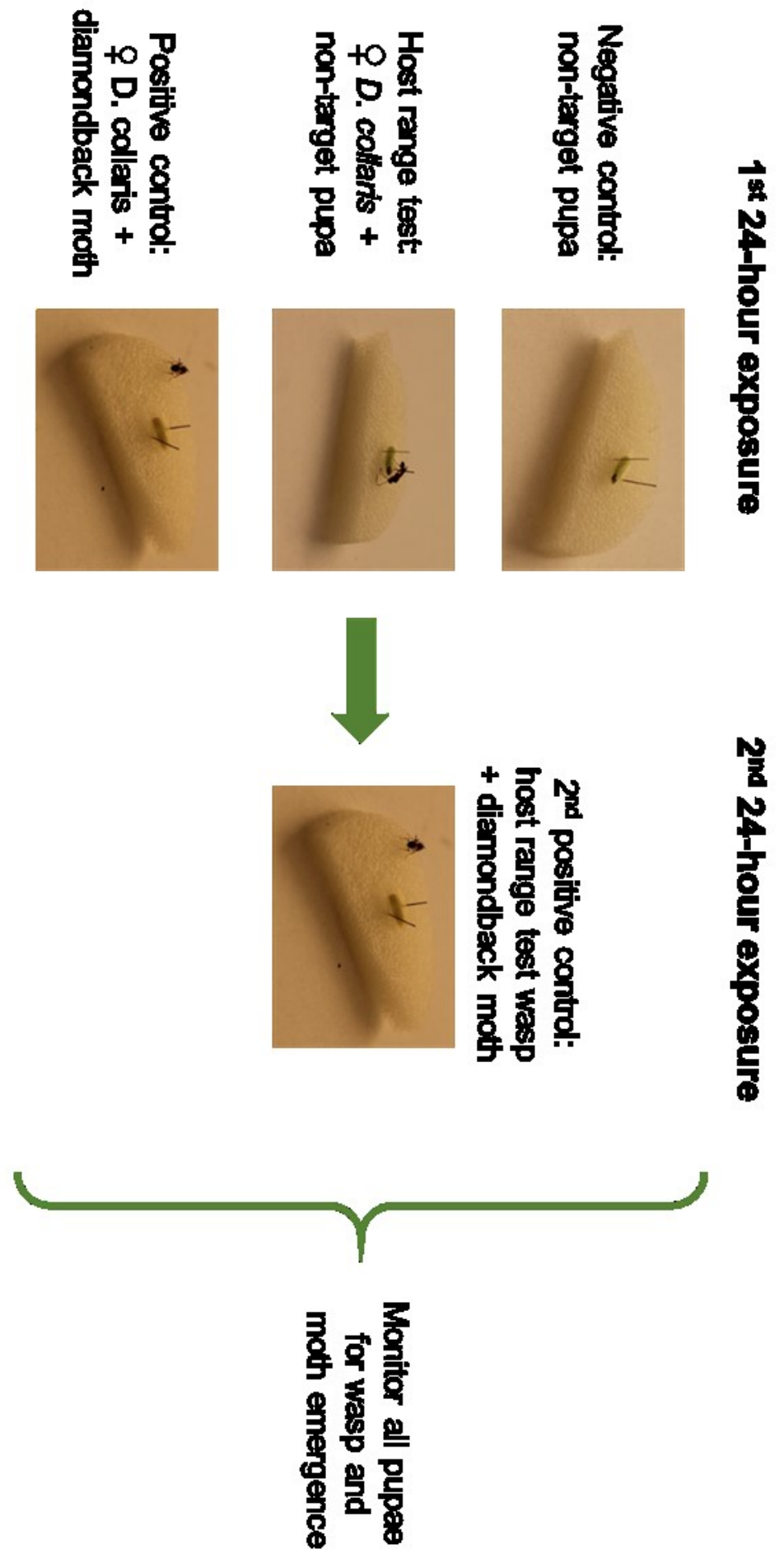

Figure 3.1: Schematic of no-choice host range tests for the determination of the fundamental host range of Diadromus collaris. 


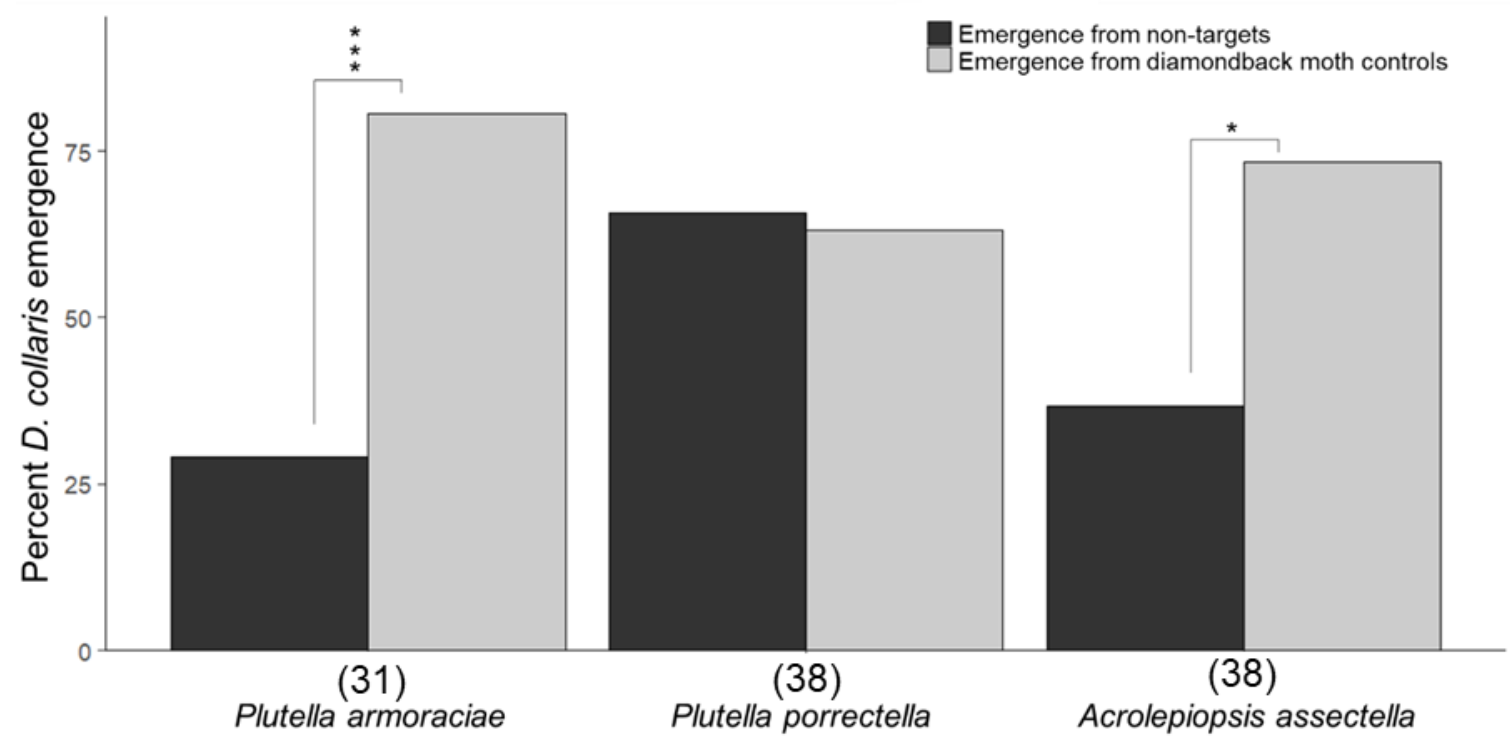

Figure 3.2: Percent Diadromus collaris emergence from non-target species Plutella porrectella, Plutella armoraciae and Acrolepiopsis assectella compared to percent emergence from simultaneous target diamondback moth controls after a $24 \mathrm{~h}$ exposure $\left({ }^{*} \mathrm{p}<0.05^{* * *} \mathrm{p}<0.001\right)$. The number of replicates for each species are shown in parenthesis. 
collaris exposed pupae

Non-exposed control pupae

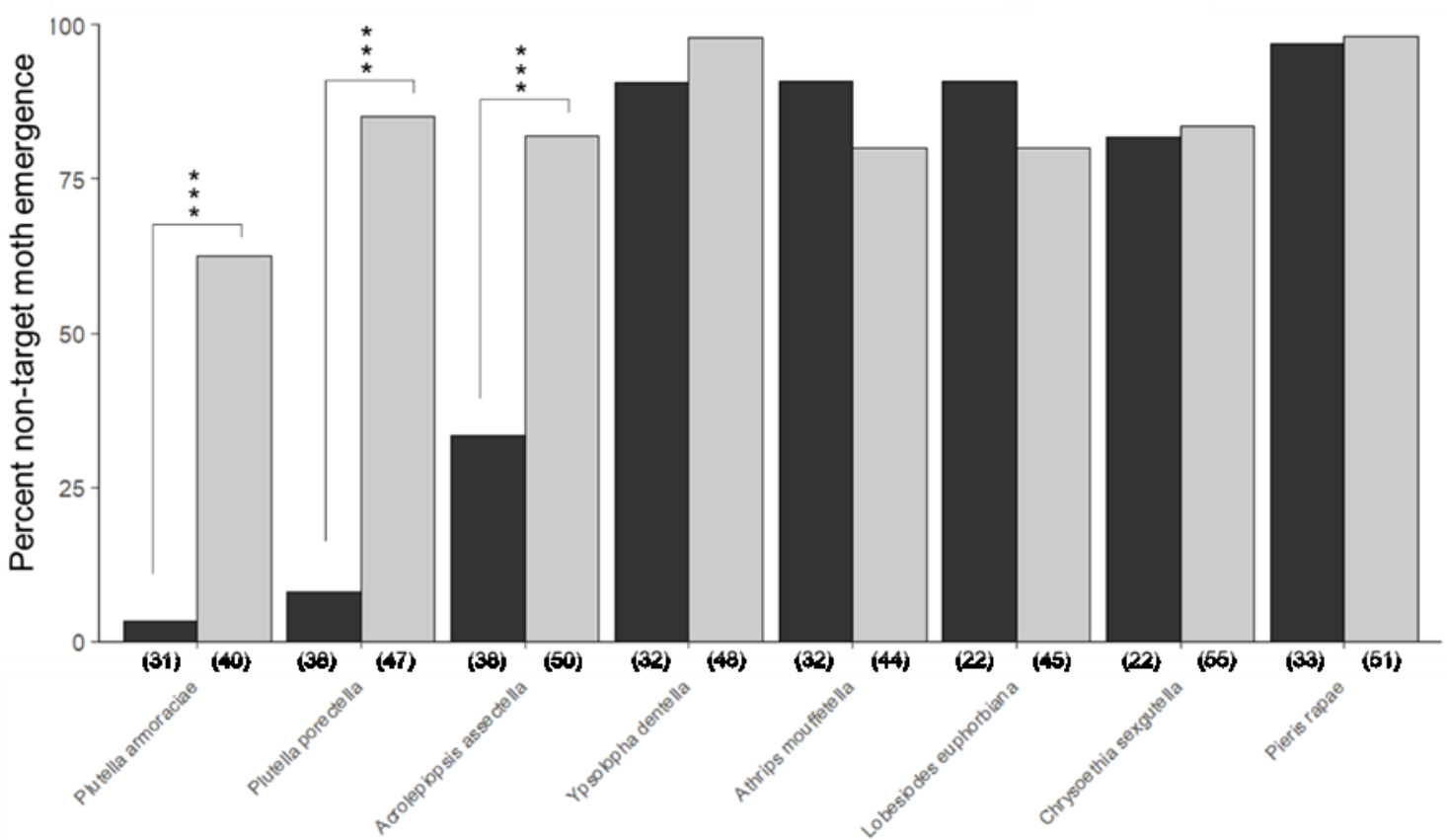

Figure 3.3: Moth emergence from the non-target species Plutella porrectella, Plutella armoraciae, Acrolepsis assectella, Ypsolopha dentella, Athrips mouffetella, Lobesiodes euphorbiana and Pieris rapae exposed to Diadromus collaris for 24 hours compared to emergence from non-target control pupae not exposed to wasps $(* * * \mathrm{p}<0.001)$. The number of replicates for each species and treatment are shown in parenthesis. 


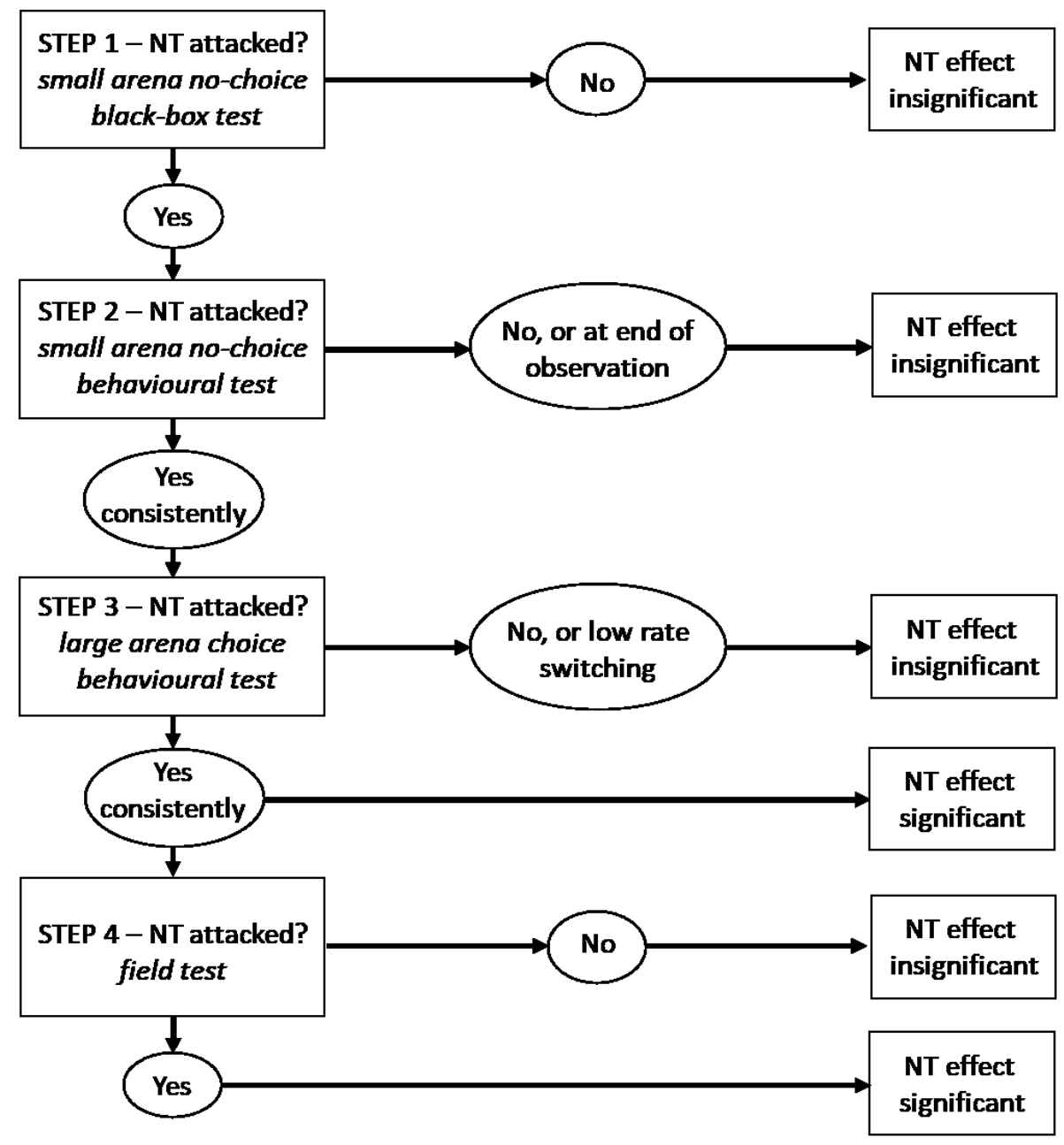

Figure 3.4: Flow-chart adapted from van Lenteren et al. (2006) depicting a hierarchical approach to host range testing for candidate biological control agents (NT= non-target). 


\section{Chapter 4: General Conclusion.}

Biological control is a critical component of IPM for diamondback moth, particularly in light of its widespread evolution of resistance to insecticides (Verkerk and Wright, 1996). The pupal parasitoid Diadromus collaris is a promising candidate for introduction into Canada, where the native natural enemy populations do not provide sufficient control in years of economically significant outbreak. The self-sustaining nature of biological control as a management strategy makes it an appealing solution, but the irreversibile nature of such introductions does add an element of risk. It is important to consider the potential for negative effects to non-target species before D. collaris is released, and in particular, the potential for host range expansion to non-target species. Historical records indicate that D. collaris is relatively host specific (Yu et al., 2012), with only three known hosts (one of which is the target pest), but nonetheless it is important to test the parasitoid's host specificity empirically. The aim of this thesis was to begin the host specificity testing of $D$. collaris by determining the parasitoid's fundamental host range.

\section{Summary of findings}

My first aim was to design a test protocol that would maximize the expressed host range of $D$. collaris. I investigated five experimental parameters to determine how they may affect the wasp's motivational state, using parasitoid offspring emergence and/or diamondback moth mortality as a proxy for the wasp's motivation to oviposit. Offspring emergence varied significantly among diet treatment types, but post-hoc Tukey's comparison tests showed no significant differences among the different diet treatments, likely due to the large number of pairwise comparisons. The effect of exposure length was 
statistically significant: an exposure of 24 hours resulted in significantly higher wasp emergence than a 12-hour exposure. Diadromus collaris emergence did not differ significantly between diamondback moth pupae exposed with or without a cocoon, but total diamondback moth mortality was significantly higher for pupae that were exposed with their cocoons intact than for pupae exposed without cocoons. Tests of wasp age and substrate type did not result in statistically significant differences in D. collaris emergence. The results from this study were applied to maximize the motivational state of $D$. collaris during its host specificity testing by implementing the following testing parameters: a diet of sucrose and pollen, three- to seven-day-old wasps, non-target pupae presented without the presence of plant material, a 24-hour exposure length, and intact non-target pupal cocoons.

My next aim was to determine the fundamental host range of $D$. collaris using a series of no-choice black box tests. Eight species of non-target Lepidoptera were selected based on their phylogenetic, morphological and ecological similarities to the diamondback moth, or as safeguard species. I exposed pupae from these species to female $D$. collaris to determine whether any were suitable for parasitoid development and/or whether exposure to D. collaris increased non-target mortality. Three of the non-target species (Plutella armoraciae, Plutella porrectella, and Acroplepiposis assectella) were suitable for $D$. collaris development. These three species also exhibited significantly higher mortality as a result of exposure to $D$. collaris. Diadromus collaris emergence from $P$. porrectella was not significantly different from emergence from diamondback moth controls, indicating a high level of suitability. Wasp emergence was significantly lower from the non-targets $A$. assectella and $P$. armoraciae than from their diamondback moth controls. This suggests 
that $A$. assectella and $P$. armoraciae are either less preferred or less suitable for development than the target diamondback moth. For the remaining five species, Ypsolopha dentella, Athrips mouffetella, Chrysoesthia sexguttella, Pieris rapae, and Lobesiodes euphorbiana, exposure to $D$. collaris did not result in any significant difference in moth emergence compared to non-exposed control pupae. These findings indicate that the fundamental host range of $D$. collaris is limited to species that share a close phylogenetic relationship with the target species, the diamondback moth. The results from this study may be used to develop hypotheses about the effect the parasitoid could have on non-target species under field conditions.

\section{Future directions}

While it is now clear that $D$. collaris can successfully parasitize some non-target Plutellidae and Glyphipterigidae, further research is required to determine how severe these non-target effects may be. Moving forward, it is necessary to assess the potential for nontarget effects in the recorded host Lobesia botrana, the safeguard species Prays atomocella, and species in the sub-family Glyphipteriginae. In addition, $P$. armoraciae, $P$. porrectella, and $A$. assectella should be evaluated using choice and large arena tests to further investigate the host preferences of $D$. collaris. This research will provide a more accurate assessment of the risk for host range expansion.

Although this thesis focused exclusively on the parasitoid's host specificity, an additional concern is how $D$. collaris may interact with native natural enemy species already present in the ecosystem (Miall et al., 2018). There is the potential for competitive interactions between $D$. collaris and the native pupal parasitoid Diadromus subtilicornis (Gravenhorst) (Hymenoptera: Ichneumonidae). Because introduced species are often 
competitively superior (Reitz and Trumble, 2002), D. collaris may displace native parasitoids. Alternatively, interspecific competition between native and introduced species could prevent the successful establishment of $D$. collaris or reduce the efficacy of the parasitoid complex against the target pest (Denoth et al., 2002). Prior to its introduction into Canada, the interactions between D. collaris and other species from the existing parasitoid community should be evaluated.

\section{Final conclusions}

This study of the fundamental host range of $D$. collaris offers insight into the parasitoid's host specificity and valuable direction for future research. While further testing is required before the parasitoid is released into Canada, the results from this thesis do not

provide any evidence to reject $D$. collaris as a candidate agent for release against the diamondback moth. 


\section{References}

Abram, P. K., Brodeur, J., Burte, V., \& Boivin, G. (2016). Parasitoid-induced host egg abortion: an underappreciated component of biological control services provided by egg parasitoids. Biological Control, 98: 52-60.

Barratt, B. I. P., Howarth, F. G., Withers, T. M., Kean, J. M., \& Ridley, G. S. (2010). Progress in risk assessment for classical biological control. Biological control, 52: 245-254.

Bekkaoui, A., \& Thibout, E. (1993). Role of the cocoon of Acrolepiopsis assectella (Lep., Hyponomeutoidae) in host recognition by the parasitoid Diadromus pulchellus (Hym., Ichneumonidae). Entomophaga, 38: 101-113.

Boettner, G. H., Elkinton, J. S., \& Boettner, C. J. (2000). Effects of a biological control introduction on three nontarget native species of saturniid moths. Conservation Biology, 14: 1798-1806.

Braun, L., Olfert, O., Soroka, J., Mason, P., Dosdall, L. M., Kirk, A. A., \& Bordet, D. (2004). Diamondback moth biocontrol activities in Canada. Improving biocontrol of Plutella xylostella, 144-146.

Charleston, D. S., Kfir, R., Dicke, M., \& Vet, L. E. (2005). Impact of botanical pesticides derived from Melia azedarach and Azadirachta indica on the biology of two parasitoid species of the diamondback moth. Biological Control, 33: 131-142.

Cameron, P. J., \& Walker, G. P. (1997). Host specificity of Cotesia rubecula and Cotesia plutellae, parasitoids of white butterfly and diamondback moth. In PROCEEDINGS OF THE NEW ZEALAND PLANT PROTECTION CONFERENCE (pp. 236-241). NEW ZEALAND PLANT PROTECTION SOCIETY INC.

Chua, T. H., \& Ooi, P. A. C. (1986, March). Evaluation of three parasites in the biological control of diamondback moth in the Cameron Highlands, Malaysia. In Diamondback Moth Management: Proceedings of the First International Workshop (pp. 173-184). Asian Vegetable Research and Development Center, Shanhua, Taiwan.

Dancau, T., Mason, P. G., \& Cappuccino, N. (2018). Elusively overwintering: a review of diamondback moth (lepidoptera: Plutellidae) cold tolerance and overwintering strategy. The Canadian Entomologist, 159: 156-173.

Delvare, G., Kirk, A., \& Bordet, D. (2004). The taxonomic status and role of Hymenoptera in biological control of DBM, Plutella xylostella (L.) (Lepidoptera: Plutellidae). In Improving biocontrol of Plutella xylostella-Proceedings of the international symposium. CIRAD, Montpellier, France (pp. 17-49). 
Denoth, M., Frid, L., \& Myers, J. H. (2002). Multiple agents in biological control: improving the odds?. Biological control, 24: 20-30.

Dosdall, L. M., Mason, P. G., Olfert, O., Kaminski, L., \& Keddie, B. A. (2001). The origins of infestations of diamondback moth, Plutella xylostella (L.), in canola in western Canada. In The management of diamondback moth and other crucifer pests. Proceedings of the Fourth International Workshop (pp. 26-29).

Dosdall, L. M. (2008). Diamondback moth, Plutella xylostella (L.), as a pest of canola in Canada: Its historical impact on the crop and predicted effects of climate change on its pest status. In Proceedings of the Fifth International Workshop on the Management of Diamondback Moth and Other Crucifer Pests, Beijing, China, 24-27 October 2006 (pp. 112-121). China Agricultural Science and Technology Press.

Dosdall, L. M., Soroka, J. J., \& Olfert, O. (2011). The diamondback moth in canola and mustard: current pest status and future prospects. Prairie Soils Crops Journal, 4: 6676.

Fisher, T. W., Bellows, T. S., Caltagirone, L. E., Dahlsten, D. L., Huffaker, C. B., \& Gordh, G. (Eds.). (1999). Handbook of biological control: principles and applications of biological control. Elsevier.

Froud, K. J., \& Stevens, P. S. (2002, January). Importation biological control of Heliothrips haemorrhoidalis by Thripobius semiluteus in New Zealand-a case study of non-target host and environmental risk assessment. In Proceedings of the 1st International Symposium on Biological Control of Arthropods, Honolulu, Hawaii (pp. 14-18).

Fujiwara, C., Takabayashi, J., \& Yano, S. (2000). Oviposition experience on a host-infested plant affects flight and antennal searching behavior of Cotesia kariyai toward the hostplant complex. Entomologia Experimentalis et Applicata, 97: 251-256.

Furlong, M. J., Shi, Z. H., Liu, S. S., \& Zalucki, M. P. (2004). Evaluation of the impact of natural enemies on Plutella xylostella L. (Lepidoptera: Yponomeutidae) populations on commercial Brassica farms. Agricultural and Forest Entomology, 6: 311-322.

Furlong, M. J., Wright, D. J., \& Dosdall, L. M. (2013). Diamondback moth ecology and management: problems, progress, and prospects. Annual review of entomology, 58: 517-541.

Goodwin, S. (1979). Changes in Numbers in the Parasitoid Complex Associated With the Diamond-Back Moth, Plutella Xylostella (L.) (Lepidoptera), in Victoria. Australian Journal of Zoology, 27: 981-989.

Hamilton, J. T. (1979). Seasonal abundance of 'Pieris rapae'(L.),'Plutella xylostella'(L.) and their diseases and parasites. General and Applied Entomology: The Journal of the Entomological Society of New South Wales, 11: 59. 
Harcourt, D. G. (1954). The Biology and Ecology of the Diamondback Moth, Plutella maculipennis (Curt.) (Doctoral dissertation, Cornell University).

Harris, P. (1984). Carduus nutans L., nodding thistle and C. acanthioides L., plumeless thistle (Compositae). In Biological Control Programmes against Insects and Weeds in Canada 1969-1980 (pp.115-126). Commonwealth Agricultural Bureaux, Farnham Royal, England.

Haye, T., Goulet, H., Mason, P. G., \& Kuhlmann, U. (2005). Does fundamental host range match ecological host range? A retrospective case study of a Lygus plant bug parasitoid. Biological Control, 35: 55-67.

Jenner, W. H. (2009). Evaluation of a candidate classical biological control agent and critical assessment of suggested host specificity testing guidelines (Doctoral dissertation, Carleton University).

Jenner, W. H., Kuhlmann, U., Cappuccino, N., \& Mason, P. G. (2012). Manipulation of parasitoid state influences host exploitation by Diadromus pulchellus Wesmael (Hymenoptera: Ichneumonidae). Biological Control, 63: 264-269.

Jenner, W. H., Kuhlmann, U., Miall, J. H., Cappuccino, N., \& Mason, P. G. (2014). Does parasitoid state affect host range expression?. Biological control, 78: 15-22.

Jervis, M. A., \& Kidd, N. A. C. (1986). Host-feeding strategies in hymenopteran parasitoids. Biological Reviews, 61: 395-434.

Kalmes, R., Hedderwick, M. P., Rojas-Rousse, D., \& Chessel, D. (1983). Interactions between two parasitoids, Diadromus collaris and D. pulchellus (Ichneumonidae): Survival of male larvae in the chrysalids of Acrolepiopsis assectella subject to intraor interspecific competition.). Canadian Journal of Zoology/Revue Canadienne de Zoologie, 61: 627-632.

Keane, R. M., \& Crawley, M. J. (2002). Exotic plant invasions and the enemy release hypothesis. Trends in ecology \& evolution, 17: 164-170.

Kuhlmann, U., Schaffner, U., \& Mason, P. G. (2006). Selection of non-target species for host specificity testing. Environmental impact of invertebrates for biological control of arthropods: methods and risk assessment. CABI Publishing, Wallingford, 15-37.

Lecomte, C., \& Pouzat, J. (1985). Réponses électroantennographiques de deux parasitoïdes Ichneumonidés, Diadromus pulchellus et Diadromus collaris, aux odeurs de végétaux, $\mathrm{du}$ phytophage-hôte Acrolepiopsis assectella et du partenaire sexuel. Entomologia experimentalis et applicata, 39: 295-306. 
Liu, S. S., Wang, X. G., Guo, S. J., He, J. H., \& Shi, Z. H. (2000). Seasonal abundance of the parasitoid complex associated with the diamondback moth, Plutella xylostella (Lepidoptera: Plutellidae) in Hangzhou, China. Bulletin of entomological research, 90: 221-231.

Liu, S. S., Wang, X. G., Shi, Z. H., \& Gebremeskel, F. B. (2001). The biology of Diadromus collaris (Hymenoptera: Ichneumonidae), a pupal parasitoid of Plutella xylostella (Lepidoptera: Plutellidae), and its interactions with Oomyzus sokolowskii (Hymenoptera: Eulophidae). Bulletin of entomological research, 91: 461-469.

Liu, S. S., Chen, F. Z., \& Zalucki, M. P. (2002). Development and survival of the diamondback moth (Lepidoptera: Plutellidae) at constant and alternating temperatures. Environmental Entomology, 31: 221-231.

Lloyd, D. C. (1940). Host selection by hymenopterous parasites of the moth Plutella maculipennis Curtis. Proceedings of the Royal Society of London. Series B-Biological Sciences, 128: 451-484.

Louda, S. M., Kendall, D., Connor, J., \& Simberloff, D. (1997). Ecological effects of an insect introduced for the biological control of weeds. Science, 277: 1088-1090.

Madder, D. J., \& Stemeroff, M. (1988). The economics of insect control on wheat, corn, and canola in Canada, 1980-1985. The economics of insect control on wheat, corn, and canola in Canada, 1980-1985., 20 (2, Supplement).

Mason, P. G., Brauner, A. M., Miall, J. H., \& Bennett, A. M. R. (2013). Diadromus pulchellus in North America: field release against leek moth and new characters to distinguish it from Diadromus subtilicornis, a native diamondback moth parasitoid. Biocontrol science and technology, 23: 260-276.

Miall, J. (2018). The parasitoid community associated with the invasive leek moth, Acrolepiopsis assectella (Zeller)(Lepidoptera: Acrolepiidae): can conservation biological control benefit an introduced classical biological control agent in North America? (Master's thesis, Carleton University).

Meyer, N. F. (1934). Schlupfwespen, die in Russland in den letzten Jahren aus Schädlingen gezogen sind. Zeitschrift für Angewandte Entomologie, 20: 611-618.

Meyrick, E. (1928). A Revised Handbook of British Lepidoptera. A Revised Handbook of British Lepidoptera.

Minkenberg, O. P., Tatar, M., \& Rosenheim, J. A. (1992). Egg load as a major source of variability in insect foraging and oviposition behavior. Oikos, 134-142. 
Morehead, S. A., \& Feener, D. H. (2000). An experimental test of potential host range in the ant parasitoid Apocephalus paraponerae. Ecological Entomology, 25: 332-340.

Onstad, D. W., \& McManus, M. L. (1996). Risks of host range expansion by parasites of insects. BioScience, 46: 430-435.

Petitt, F. L., Turlings, T. C. J., \& Wolf, S. P. (1992). Adult experience modifies attraction of the leafminer parasitoid Opius dissitus (Hymenoptera: Braconidae) to volatile semiochemicals. Journal of Insect Behavior, 5: 623-634.

Pimentel, D. (1986). Biological invasions of plants and animals in agriculture and forestry. In Ecology of biological invasions of North America and Hawaii (pp. 149-162). Springer, New York, NY.

R core Team. (2000). R language definition, Version 3.4.4. Vienna, Austria: R foundation for statistical computing.

Reitz, S. R., \& Trumble, J. T. (2002). Competitive displacement among insects and arachnids. Annual review of entomology, 47: 435-465.

Sakanoshita, A., Ohta, M., \& Uematsu, H. (1987). Comparative study of ovogenesis in the parasitoids of the diamondback moth, Plutella xylostella. Proceedings of the Association for Plant Protection of Kyushu (Japan).

Sandlan, K. (1980). Host location by Coccygomimus turionellae (Hymenoptera: Ichneumonidae). Entomologia Experimentalis et Applicata, 27: 233-245.

Sands, D. P. A., \& Van Driesche, R. G. (2004). Using the scientific literature to estimate the host range of a biological control agent. Assessing host ranges for parasitoids and predators used for classical biological control: a guide to best practice. USDA Forest Health Technology Enterprise Team, Morgantown, 15-23.

Sarfraz, M., Keddie, A. B., \& Dosdall, L. M. (2005). Biological control of the diamondback moth, Plutella xylostella: a review. Biocontrol Science and Technology, 15: 763-789.

Sohn, J. C., Regier, J. C., Mitter, C., Davis, D., Landry, J. F., Zwick, A., \& Cummings, M. P. (2013). A molecular phylogeny for Yponomeutoidea (Insecta, Lepidoptera, Ditrysia) and its implications for classification, biogeography and the evolution of host plant use. Plos one, 8: e55066.

Talekar, N. S., \& Shelton, A. M. (1993). Biology, ecology, and management of the diamondback moth. Annual Review of Entomology, 38: 275-301.

Telenga, N. (1934). Parasiten und ihre Bedeutung in der Dynamik des Traubenwicklers (Polychrosis botrana Schiff.). Anzeiger für Schädlingskunde, 10: 101-106. 
Valemberg, J., \& Vago, J. L. (1974). Nomenclature des Ichneumoninae hibernant du Cambresis. Bull Soc Entomol Nord Fr, 193: 1-4.

Van Driesche, R. G., \& Murray, T. J. (2004). Overview of testing schemes and designs used to estimate host ranges. Assessing host ranges for parasitoids and predators used for classical biological control: a guide to best practice, $R G$ Van Driesche and $R$. Reardon (Ed.) USDA Forest Service, Morgantown, West Virginia, 68-89.

van Lenteren, J. C., Babendreier, D., Bigler, F., Burgio, G., Hokkanen, H. M. T., Kuske, S., Loomans, A.J.M., Menzler-Hokkanen, I., Van Rijn, P.C.J., Thomas, \& Tommasini, M. G. (2003). Environmental risk assessment of exotic natural enemies used in inundative biological control. BioControl, 48: 3-38.

Van Lenteren, J. C., Bale, J., Bigler, F., Hokkanen, H. M. T., \& Loomans, A. J. M. (2006). Assessing risks of releasing exotic biological control agents of arthropod pests. Annual Review of Entomology, 51: 609-634.

Verkerk, R. H., \& Wright, D. J. (1996). Multitrophic interactions and management of the diamondback moth: a review. Bulletin of Entomological Research, 86: 205-216.

Vet, L. E., \& Dicke, M. (1992). Ecology of infochemical use by natural enemies in a tritrophic context. Annual Review of Entomology, 37: 141-172.

Vet, L. E., Lewis, W. J., \& Carde, R. T. (1995). Parasitoid foraging and learning. In Chemical ecology of insects 2 (pp. 65-101). Springer, Boston, MA.

Vinson, S. B. (1976). Host selection by insect parasitoids. Annual Review of Entomology, 21: 109-133.

Vitousek, P. M., D'antonio, C. M., Loope, L. L., Rejmanek, M., \& Westbrooks, R. (1997). Introduced species: a significant component of human-caused global change. New Zealand Journal of Ecology, 21(1), 1-16.

WCCP. 1995. Minutes of the $34^{\text {th }}$ Annual Meeting of the Western Committee on Crop Pests, October 19-21, Victoria, British Columbia, Canada. 44 pp.

WCCP. 2001. Minutes of the $41^{\text {st }}$ Annual Meeting of the Western Committee on Crop Pests, October 15-16, Banff, Alberta, Canada. 71 pp.

Withers, T. M., \& Browne, L. B. (2004). Behavioral and physiological processes affecting outcomes of host range testing. Assessing host ranges for parasitoids and predators used for classical biological control: A guide to best practice, 40-55.

Withers, T., \& Mansfield, S. (2005). Choice or no-choice tests? Effects of experimental design on the expression of host range. In Second International Symposium on Biological Control of Arthropods, Davos, Switzerland, 12-16 September, 2005 (pp. 620-633). United States Department of Agriculture, Forest Service. 
Yu, D.S., van Achterberg, C.V. and Horstmann, K., 2012. Taxapad 2012, Ichneumonoidea 2011. Database on flash-drive. Ottawa, Ontario, Canada. Available online at: http://www.taxapad.com/index.php

Zalucki, M. P., Shabbir, A., Silva, R., Adamson, D., Shu-Sheng, L., \& Furlong, M. J. (2012). Estimating the economic cost of one of the world's major insect pests, Plutella xylostella (Lepidoptera: Plutellidae): just how long is a piece of string?. Journal of Economic Entomology, 105: 1115-1129. 


\section{Appendix 1: Supplementary Figures}

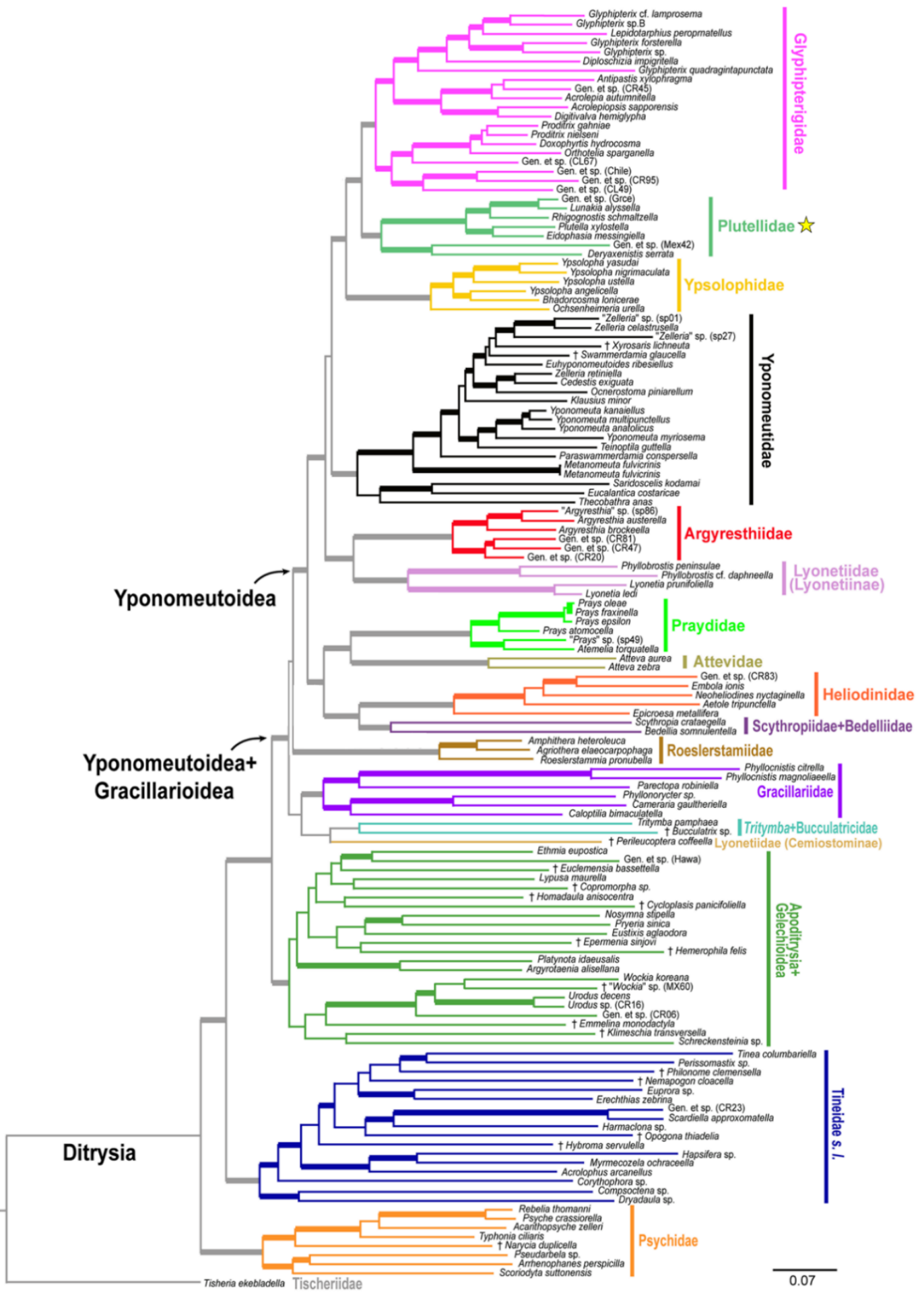

Figure A1: Phylogram representation of the maximum likelihood genetic analysis tree for Yponomeutoidea. Plutella xylostella belongs to the Plutellidae (highlighted with a star). Modified from Sohn et al. (2013). 